Article

\title{
Human Immunodeficiency Virus Proteins Mimic Human T Cell Receptors Inducing Cross-Reactive Antibodies
}

\author{
Robert Root-Bernstein \\ Department of Physiology, Michigan State University, 567 Wilson Road, Room 2201, East Lansing, MI 48824, \\ USA; rootbern@msu.edu; Tel.: +1-517-884-5039
}

Received: 22 August 2017; Accepted: 28 September 2017; Published: 3 October 2017

\begin{abstract}
Human immunodeficiency virus (HIV) hides from the immune system in part by mimicking host antigens, including human leukocyte antigens. It is demonstrated here that HIV also mimics the V- $\beta$-D-J- $\beta$ of approximately seventy percent of about 600 randomly selected human $T$ cell receptors (TCR). This degree of mimicry is greater than any other human pathogen, commensal or symbiotic organism studied. These data suggest that HIV may be evolving into a commensal organism just as simian immunodeficiency virus has done in some types of monkeys. The gp120 envelope protein, Nef protein and Pol protein are particularly similar to host TCR, camouflaging HIV from the immune system and creating serious barriers to the development of safe HIV vaccines. One consequence of HIV mimicry of host TCR is that antibodies against HIV proteins have a significant probability of recognizing the corresponding TCR as antigenic targets, explaining the widespread observation of lymphocytotoxic autoantibodies in acquired immunodeficiency syndrome (AIDS). Quantitative enzyme-linked immunoadsorption assays (ELISA) demonstrated that every HIV antibody tested recognized at least one of twelve TCR, and as many as seven, with a binding constant in the $10^{-8}$ to $10^{-9} \mathrm{~m}$ range. HIV immunity also affects microbiome tolerance in ways that correlate with susceptibility to specific opportunistic infections.
\end{abstract}

Keywords: acquired immunodeficiency syndrome; antigenic mimicry; lymphocytotoxic autoantibodies; autoimmunity; holoimmunity; autoholoimmunity; microbiome; tolerance

\section{Introduction}

This study explores the nature of the immune response to human immunodeficiency virus infection (HIV) in light of the concepts of holoimmunity and autoholoimmunity. In particular, the mimicry of HIV for human T cell receptors (TCR) is explored; its consequences for understanding the antilymphocyte autoimmunity associated with acquired immunodeficiency syndrome (AIDS) examined; and the difficulties that it poses for vaccine development considered.

Recent research strongly suggests that organisms are not composed merely of their genetically encoded components, but develop and evolve as commensal and mutualistic super-organisms, or holobionts, that include the entire microbiome associated with the host [1,2]. Root-Bernstein [3] recently introduced the concept of holoimmunity to describe the commensal relationship between the microbiome and its host immune system. The fundamental principle of holoimmunity is that commensal or mutualistic microbes evolve to mimic not just host antigens, as Damien proposed in 1962, but the host immune system, and particularly T cell receptor (TCR) sequences, as closely as possible so as to acquire molecular camouflage from the immune system [3-6]. Selection for the microbiome is therefore mediated by the immune system. Tolerance within the immune system of an organism is therefore developed not just to its own molecular constituents, but also the molecular constituents of its integral microbiome. The immune system determines not only what microbes are pathogenic, but also what microbes are 
capable of interacting with the host as commensal or symbiotic constituents making up a "holobiont". Root-Bernstein has called the system that mediates holobiont health "holoimmunity" [3].

The concept of "holoimmunity" leads logically to the concept of "autoholoimmunity". Just as autoimmunity can result when the immune system attacks "self" antigens, autoholoimmunity can occur when the immune system turns against both "self" and microbiome antigens simultaneously. Since microbiome composition is chosen by similarity to host proteins so as to avoid immune surveillance, every microbe within the host microbiome will mimic some set of host antigens. If an autoimmune disease is triggered against such a host antigen, then the immune system will also be likely to attack those microbiome constituents that mimic the host antigen. Such cross-reactivity of the immune response may explain why every autoimmune disease is characterized by attacks on specific components of its microbiome (reviewed in [3]). Hence the term "autoholoimmunity", since both host and microbiome are immune system targets. Additionally, a previously unrecognized aspect of such autoimmunity and autoholoimmuniity is that the immune system itself, which mimics both the host and the microbiome, can become one of the targets of attack [3].

Human immunodeficiency virus (HIV) mimicry of host antigens has been documented since the origins of the AIDS epidemic. HIV has a variety of means to avoid activating the immune system. HIV subverts various innate immunity mechanisms by downregulating toll-like receptor 9 (TLR 9); replicating too inefficiently in dendritic cells to trigger a response; and harnessing the host cytoplasmic DNAase Three-Prime Repair Exonuclease 1 (DNase TREX1) to digest nonproductive HIV reverse transcripts [7]. In macrophages, HIV uses polyadenylation specificity factor subunit 6 and cyclophilins to cloak its replication, allowing evasion of innate immune sensors [8]. In addition, HIV can subvert the complement system thereby impeding clearance of infected cells; it directly inhibits interferon and natural killer cell activity; downregulates human leukocyte antigen (HLA) expression; and prevents proteosomal degradation processes related to virus particle clearance [9]. Finally, HIV also mimics many host proteins, essentially camouflaging itself from the immune system by cloaking itself with the same tolerance mechanisms that protect the host from autoimmunity.

It has long been known that HIV mimics a wide variety of human proteins (reviewed in: [10-17]. The human proteins mimicked by HIV include the human leucocyte antigens (HLA) [18-28]; CD4+ $\mathrm{T}$ cell antigens [24,25,29-34]; interferons and interleukins [35-37]; NF- $\mathrm{kB}$ [38]; blood coagulation proteins [26-28,39-45]; integrin [46]; the substrates for cleavage and polyadenylation specificity factor subunit 6 (CPSF6) and cyclophilins (Nup358 and CypA) [8]; Hrs protein [47]; astrocyte proteins [48-52]; as well as a highly conserved, but unidentified, human antigen [4-6,53]. While exploring TCR similarities to various human and microbial proteins, it became apparent that HIV also mimics the hypervariable antigen recognition region of most human TCR.

The ability of the immune system to respond to a wide range of antigens depends on a process of recombination between diverse genetically encoded sequences and the generation of highly variable linkers that join these encoded sequences. In $\mathrm{T}$ cells, which implement cellular immunity and mediate $\mathrm{B}$ cell activation, these genetically encoded regions are made up of CD3 V- $\beta$ and J- $\beta$ sequences joined by D (diversity) linkers [54]. Each CD3 V- $\beta$-D-J- $\beta$ sequence is presumed to have a high degree of specificity for a small number of MHC-restricted antigens. These TCR sequences are often subject to analysis with regard to their selective amplification in particular diseases. The assumption behind such studies is that CD3 V- $\beta$-D-J- $\beta$ sequences are disease-specific and can reveal important information about antigen restriction.

Recent analysis of CD3 V- $\beta$-D-J- $\beta$ regions of T cell receptors (TCR) from human beings has yielded the surprising observation that TCR sequences always mimic several (and sometimes many) other human proteins [3]. A further observation is that microbes that co-exist with the host as symbiotic, commensal, chronic or latent infections are much more likely to mimic TCR V- $\beta$-D-J- $\beta$ regions than are acutely infectious microbes. In other words, microbes to which the immune system is tolerant are much more likely to mimic both host antigens and host TCR than are pathogens [3-6].

Selecting for a repertoire of TCR and B cell receptors (BCR) that mimic the protein sequences of the host leads to important implications for understanding how microbiome constituents are selected. TCR 
that are highly reactive to their host are eliminated during development leaving TCR that mimic (and therefore are non-reactive with) host antigens. The immune system therefore represents a simplified "body double" of the entire range of host antigens. Thus, the immune system can intercept and "interrogate" potentially adverse insults to the body by presenting and amplifying TCR and BCR that can prevent these insults from interacting with other host proteins. Any microbe or toxin that can interact with this "body double" has a high probability of also interacting (potentially catastrophically) with the host and therefore needs to be neutralized before it does so. Conversely, organisms and nutrients that can be beneficial to the host need to be composed of materials that either mimic the immunological "body double" or are invisible to it by not interacting with it at all. The microbiome co-exists with its host by camouflaging its components through mimicry of both host and immune system "self" (holoimmunity) [3]. Unfortunately, this molecular camouflage can produce unwanted effects as a result of autoimmune reactions. Autoantibodies can attack not just host antigens, but also the microbial mimics of these host antigens; and conversely, an immunological attack on microbiome constituents raises the risk of cross-reactivity against host mimics. Thus, every autoimmune disease results in the development of lack of tolerance to specific microbiome components, or autoholoimmunity (reviewed in [3]).

The principle that immunological "self" is encoded within TCR and BCR sequences provides a basis for analyzing the degree to which any particular microbe or antigen is likely to be able to "hide" or "camouflage" itself from the immune system by mimicking these determinants of "self" [3-6]. In particular, it is demonstrated here that HIV has evolved to mimic the T cell receptor repertoire of its host in order to avoid immune surveillance. Because of HIV mimicry of immune system antigens, if 5 the immune system is activated to attack HIV, it has a high likelihood of producing immune responses that target not just HIV, but also TCR. Thus, HIV mimicry of TCR creates a high probability of inducing antilymphocyte autoimmunity in the host and poses significant difficulties for HIV vaccine development.

\section{Results}

Overall, the results of this study demonstrate that HIV mimics human TCR to a higher degree than any other microbe thus far examined, including commensal, mutualistic and symbiotic organisms, chronic infectious agents, and common human pathogens. This mimicry translates into anti-HIV antibodies that have a high probability of recognizing human TCR sequences with affinities associated with active autoimmune disease, at least under in vitro conditions.

Figure 1 provides an example of the data generated for each TCR showing that there is a high degree of similarity between human TCR and multiple viral, bacterial and protozoal proteins. Similar data were generated for all of the 520 normal and patient TCR used in the study, the 109 HIV-associated TCR sequences, and the 201 control TCR sequences. These data were then used to generate Tables 1 and 2, which summarize the aggregated results in terms of the percent of TCR mimicking each of the listed microbes. Statistically significant differences in these percentages are provided.

Table 1 displays two phenomena. First HIV mimics randomly selected human TCR at an unexpectedly high rate compared to any other common human viruses (average $71 \%$ as compared with the next highest mimicry rates, displayed by hepatitis $C$ virus, cytomegalovirus and influenza $A$ virus, each of which mimic human TCR only about $20 \%$ of the time). This rate was significantly higher than randomized TCR controls $(60 \%)$ and it is highly and significantly enriched among TCR derived from HIV-infected people (87\%).

Secondly, Table 1 also shows that the percentage of similarities between HIV-derived TCR and proteins of other HIV-associated viral infections such as hepatitis B, hepatitis C, Epstein-Barr virus and cytomegalovirus are also significantly increased, while no such increases are seen among viruses that are not associated as HIV cofactors in AIDS.

Table 2 also illustrates two phenomena. First, comparing Table 1 with Table 2 demonstrates that HIV mimics human TCR at a higher rate than any other class of microbes, including human commensal bacteria such as the bifidobacteria, clostridia, and lactobacilli. This observation confirms the data in Table 1 showing similarly that HIV mimics human TCR at a far higher rate than any microbe known to infect human beings. 
Table 2 also illustrates the fact that TCR derived from people infected with HIV have increased similarity to a variety of bacteria and protozoal infections associated with AIDS. Significant increases in similarity compared with non-HIV populations include: corynebacteria, Crytpococcus neoformans, Enterobacteria, Enterococci, Escherichia coli, Giardia, Mycobacteria, Neisseria, Staphylococci, Streptococci, Toxoplasma gondii, Trichomonas vaginalis, and Trypanosoma cruzi. As with viruses, TCR similarity to bacteria and protozoal infections unassociated with AIDS are not significantly modified, or decrease in prevalence.

\section{HIV TCR 1 CASSEELAGGSYNE \\ I9QPSO (I9QPSO_9BACE) Uncharacterized protein OS=Bacteroides cellulosilyticus \\ Query 5 EELAGGSYNE 14 \\ $\begin{array}{llll} & \text { EEjct } 159 & \text { EELANGTYNQ } & 168\end{array}$}

ROAHA9 (ROAHA9_CLOBU) Uncharacterized protein $\mathrm{OS}=$ Clostridium butyricum

$\begin{array}{llll}\text { Query } 5 & \text { EELAGGSYN } & 13 \\ & \text { EELAG /YN } & \end{array}$

Sbjet 8 EELAGSAYN 16

K2H3R1 (K2H3R1_ENTNP) Uncharacterized protein OS=Entamoeba nuttalli (strain P19)

$\begin{array}{llll}\text { Query } & 8 & \text { AGGSYNE } & 14 \\ & & \text { AGGSYNE }\end{array}$

Sbjet 1408 AGGSYNE 1414

A0A125W4X3 (A0A125W4X3_ENTFL)

Uncharacterized protein OS=Enterococcus faecalis Query 3 SSEELAGGSYNE 14

$\begin{array}{lll}\text { Sbjet } & 58 & \text { SS +L GG+YNE } \\ \text { SSAQLEGGEYNE } & 69\end{array}$

E3GJK1 (E3GJK1_EUBLK) Glycerol-3-phosphate responsive antiterminator $O S=E u b a c t e r i u m$ limosum Query 1 CASSEEL 7

Sbjct 172 CASSEEL 178

A0A132PII5 (A0A132PII5_9MYCO) ABC transporter substrate-binding protein $\mathrm{OS}=$ Mycobacterium wolinskyi

$\begin{array}{lll}\text { Query } 6 & \text { ELAGGSYNE } & 14 \\ & & \text { ELAGG+YN+ }\end{array}$

Sbjet 203 ELAGGTYNQ 211

AOAOK1NNU9 (AOAOK1NNU9_9BACT)

Uncharacterized protein OS=Prevotella fusca

Query 6 ELAGGSYN 13

$\begin{array}{llll} & \text { ELAGGSYN } & \\ \text { Sbjet } 482 & \text { ELAGGSYN } & 489\end{array}$

D3H696 (D3H696_STRM6) Choline binding protein

Cbpl OS=Streptococcus mitis

Query 2 ASSEELAGG 10

Sbjet 210 ASSEELAGG 218

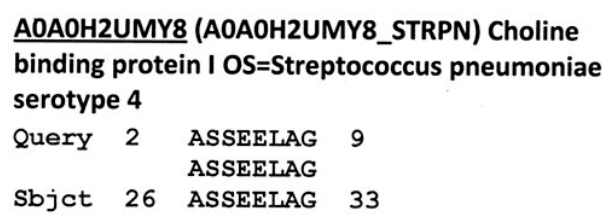

A9QNM9 (A9QNM9_9HIV1) Envelope glycoprotein (Fragment) OS=Human immunodeficiency virus 1

Query 9 GGSYNE 14

Sbjct 396 GGSYNE 401

A0A077H596 (A0A077H596_9HIV1) Envelope glycoprotein gp160 OS=Human immunodeficiency virus 1

Query 3 SSEELAG 9

$\begin{array}{llll} & \text { SSEE+AG } & \\ \text { Sbjet } & 158 & \text { SSEEMAG } & 164\end{array}$

A0A023HIC1 (AOA023HIC1_9HIV1) Gag polyprotein $O S=$ Human immunodeficiency virus 1

Query 2 ASSEEL 7

Sbjet $70 \begin{array}{ll}\text { ASSEEL } \\ \text { ASSEEL }\end{array}$

P88938 (P88938_HHV8) ORF 50 OS=Human
$\begin{array}{llll}\text { herpesvirus } 8 \text { type } & \\ \text { Query } & 2 & \text { ASSEELAGG } & 10 \\ & \text { AS EEL GG } & \\ \text { Sbjet } & 423 & \text { ASGEELPGG } & 431\end{array}$

Sbjet 423 ASGEELPG 431

P21284 (VP4_ROTHL) Outer capsid protein VP4

OS=Rotavirus A (strain Human/Philippines/L26/1987

Query 8 AGGSYN 13

Sbjet 380 AGGSYN 385

J9QCV7 (J9QCV7_9ENTO) VP2 (Fragment)

OS=Coxsackievirus B3

Query 3 SSEELAGG 10

Sbjet 58 SSEELLG 65

Figure 1. Typical (but partial) selection of HIV TCR-Microbiome protein similarities, including similarities to HIV itself (BLAST 2.0 search, UniProt protein database and virus database, $E=1000$, no gaps). Accession numbers are for the UniProt protein database (www.expasy.org). 
Table 1. HIV mimics TCR far more frequently than any other virus.

\begin{tabular}{|c|c|c|c|c|c|c|}
\hline Human Virus & $\begin{array}{c}\text { TCR } \\
\text { AVG } \% \\
N=386\end{array}$ & $\begin{array}{c}\text { Chi } 2 \\
p \text { Val } \\
\text { HIV vs. } \\
\text { AVG }\end{array}$ & $\begin{array}{c}\text { HIV } \\
\text { TCR\% } \\
N=109\end{array}$ & $\begin{array}{c}\text { Chi } 2 \\
p \text { Val } \\
\text { HIV vs. } \\
\text { Rand }\end{array}$ & $\begin{array}{c}\text { Rand + Anti } \\
\text { TCR } \% \\
N=201\end{array}$ & $\begin{array}{c}\text { Chi } 2 \\
p \text { Val } \\
\text { AVG vs. } \\
\text { Rand }\end{array}$ \\
\hline Adenovirus & 14 & & 16 & & 15.5 & \\
\hline Astrovirus & 1 & & 2 & & 2.5 & \\
\hline Bocavirus & 0.5 & & 2 & & 4 & \\
\hline Cardiovirus & 0.5 & & 0 & & 1.5 & \\
\hline Coronavirus & 5 & & 9 & & 4 & \\
\hline Coxsackie A & 5 & 0.001 & 12 & $1.3 \times 10^{-7}$ & 3 & \\
\hline Coxsackie B & 3.3 & & 4 & & 0 & \\
\hline CMV & 22.5 & & 30 & $3.1 \times 10^{-6}$ & 13.5 & \\
\hline Echoviruses & 7.2 & & 6 & & 2.5 & \\
\hline Enteroviruses & 7.3 & & 14 & $3.3 \times 10^{-7}$ & 4 & \\
\hline EBV & 8.1 & 0.003 & 16 & $4.1 \times 10^{-6}$ & 5.5 & \\
\hline HAV & 0.8 & & 4 & & 0 & \\
\hline $\mathrm{HBV}$ & 7 & $1.6 \times 10^{-5}$ & 18 & & 21.5 & $1 \times 10^{-8}$ \\
\hline $\mathrm{HCV}$ & 21.5 & $7.3 \times 10^{-5}$ & 41 & & 33 & \\
\hline $\mathrm{HEV}$ & 2.7 & & 5 & & 14 & 0.001 \\
\hline HHV1 & 4.5 & & 7 & & 14.5 & 0.004 \\
\hline HHV2 & 4.5 & 0.001 & 11 & & 7.5 & \\
\hline HHV6 & 3.7 & $8.4 \times 10^{-7}$ & 13 & & 8.5 & \\
\hline HHV8 & 3.7 & & 8 & & 8.5 & \\
\hline HIV-1 & 71.2 & $2.6 \times 10^{-6}$ & 87 & $6 \times 10^{-8}$ & 60.5 & \\
\hline HTLV I and II & 2.7 & & 2 & & 6 & \\
\hline Infl A Virus & 20.8 & & 27 & & 29 & \\
\hline Infl B virus & 1.3 & & 1 & & 5.5 & \\
\hline Infl C virus & 0.7 & & 1 & & 1 & \\
\hline Jap enc virus & 1.5 & & 3 & & 0.5 & \\
\hline Measles virus & 2.8 & & 2 & & 8 & \\
\hline Mumps virus & 0.5 & & 0 & & 3 & \\
\hline Norovirus & 5.3 & & 8 & & 5.5 & \\
\hline Papilloma virus & 15.5 & 0.003 & 29 & & 33.5 & 0.0001 \\
\hline Parainfluenza & 0.7 & & 4 & & 3 & \\
\hline Polio virus & 0.5 & & 4 & & 1 & \\
\hline Polyoma virus & 2 & & 1 & & 1.5 & \\
\hline Reovirus & 2.3 & & 3 & & 2.5 & \\
\hline RSV & 0.5 & & 2 & & 7.5 & 0.007 \\
\hline Rhinovirus & 4 & & 9 & & 5.5 & \\
\hline Rotaviruses & 6.3 & $1 \times 10^{-5}$ & 17 & & 14.5 & 0.0007 \\
\hline Rubella & 1.3 & & 2 & & 4 & \\
\hline Varicella zoster & 4.3 & & 6 & & 4 & \\
\hline
\end{tabular}

Frequency of virus proteins mimicking T cell receptors (TCR) from a variety of patient populations: TCR AVG is the average derived from (Root-Bernstein, 2016 [3]) and consists of the sum of TCR matches from NOR = normal (no infection) controls; $\mathrm{CONT}=$ people with mono-infections; $\mathrm{CD}=$ Crohn's disease; T1DM = diabetes; HIV = people with human immunodeficiency virus infections; RAND \& ANTI are hypothetical TCR generated by two methods, a random peptide generator (100 sequences) or using the antisense sequence predicted from the normal controls (101 sequences). Bolded material indicates the viruses that mimic TCR on consistently more than $10 \%$ of the time. Statistics are reported only for significant differences $(p<0.001$ by $\chi$ squared with Bonferroni correction for the multiple viruses tested). 
Table 2. HIV mimics TCR far more frequently than any bacterium, fungus or protozoa with the exception of the class of Bacteroides species.

\begin{tabular}{|c|c|c|c|c|c|c|}
\hline Human Microbe & $\begin{array}{c}\text { AVG } \\
\text { TCR } \% \\
N=386\end{array}$ & $\begin{array}{c}\text { Chi Sq } \\
p \text { Val } \\
\text { AVG vs. } \\
\text { HIV }\end{array}$ & $\begin{array}{c}\text { HIV } \\
\text { TCR } \% \\
N=109\end{array}$ & $\begin{array}{c}\text { Chi Sq } \\
p \text { Val } \\
\text { Rand vs. } \\
\text { HIV }\end{array}$ & $\begin{array}{c}\text { Rand + Anti } \\
\text { TCR \% } \\
N=201\end{array}$ & $\begin{array}{c}\text { Chi Sq } \\
p \text { Val } \\
\text { AVG vs. } \\
\text { Rand }\end{array}$ \\
\hline Bacillus cereus & 32.0 & & 37 & & 42.5 & \\
\hline Bacteroides spp. & 64.0 & & 70 & & 74 & \\
\hline Bifidobacteria & 27.5 & 0.005 & 40 & & 42.5 & 0.0008 \\
\hline Bordetella pertussis & 5.0 & & 9 & & 16.5 & 0.002 \\
\hline Campylobacter jejuni & 4.8 & & 5 & & 6 & \\
\hline Candida albicans & 3.9 & $3 \times 10^{-6}$ & 13 & & 10 & 0.0002 \\
\hline ardiobacteria & 0.5 & $7 \times 10^{-6}$ & 4 & & 8 & $<1 \times 10^{-10}$ \\
\hline Chlamydia & 5.3 & $<1 \times 10^{-10}$ & 26 & $<1 \times 10^{-10}$ & 1 & \\
\hline Clostridium spp. & 50.5 & 0.007 & 64 & & 61.5 & \\
\hline Coccidiodes spp. & 39.5 & & 33 & & 26 & \\
\hline Coprococcus & 10.5 & & 14 & & 7.5 & \\
\hline Corynebacteria & 14.0 & $<1 \times 10^{-10}$ & 43 & & 53.5 & $<1 \times 10^{-10}$ \\
\hline $\begin{array}{c}\text { Cryptococcus } \\
\text { neoformans }\end{array}$ & 1.0 & $<1 \times 10^{-10}$ & 24 & & 18.5 & $<1 \times 10^{-10}$ \\
\hline Cryptosporidium & 15.5 & & 13 & & 18 & \\
\hline Entamoeba & 6.7 & $1 \times 10^{-8}$ & 21 & & 24.5 & $<1 \times 10^{-10}$ \\
\hline Enterobacter spp. & 12.0 & $<1 \times 10^{-10}$ & 46 & 0.002 & 61 & $<1 \times 10^{-10}$ \\
\hline Enterococcus spp. & 22.3 & $6.6 \times 10^{-7}$ & 43 & 0.0002 & 26.5 & \\
\hline Escherichia coli & 26.8 & & 36 & 0.0005 & 53.5 & $9 \times 10^{-8}$ \\
\hline Eubacterium & 22.0 & 0.0007 & 36 & & 47.5 & $3.3 \times 10^{-7}$ \\
\hline Gardnerella vaginalis & 13.5 & & 9 & & 11 & \\
\hline Giardia & 11.5 & 0.0003 & 23 & & 27 & $1.2 \times 10^{-6}$ \\
\hline Haemophilus influenzae & 4.6 & & 6 & & 4 & \\
\hline Helicobacter pyelori & 7.6 & & 8 & & 7.5 & \\
\hline Histoplasmosis & 0 & & 0 & & 1 & \\
\hline Isospora & 0 & & 0 & & 0 & \\
\hline Klebsiella pneumoniae & 10.9 & & 17 & & 23.5 & \\
\hline Lactobacillus spp. & 40.0 & & 45 & 0.0001 & 63.5 & $1 \times 10^{-6}$ \\
\hline Legionella pneumophila & 6.0 & & 6 & & 11 & \\
\hline Listeria & 8.9 & & 8 & 0.008 & 16 & \\
\hline M. tuberculosis & 8.3 & 0.0004 & 18 & & 29 & $5 \times 10^{-6}$ \\
\hline $\begin{array}{c}\text { Atypical } \\
\text { Mycobacterium }\end{array}$ & 35.0 & $<1 \times 10^{-10}$ & 74 & & 76.5 & $<1 \times 10^{-10}$ \\
\hline Mycoplasma & 9.0 & & 8 & & 13.5 & \\
\hline Neisseria & 6.2 & 0.0001 & 22 & & 20.3 & 0.0005 \\
\hline Pneumocystis & 9 & & 6 & & 13 & \\
\hline Prevotella spp. & 47.5 & & 50 & & 50.5 & \\
\hline Pseudomona aeruginosa & $11.6^{*}$ & 0.002 & 21 & & 31.5 & 0.0003 \\
\hline Salmonella & 10.5 & $<1 \times 10^{-10}$ & 29 & & 29 & $<1 \times 10^{-10}$ \\
\hline Shigella dysenteriae & 4.0 & & 3 & & 5.5 & \\
\hline Staphylococcus & 12.5 & $<1 \times 10^{-10}$ & 34 & & 27.5 & 0.0008 \\
\hline Streptococcus spp. & 31.0 & $<1 \times 10^{-10}$ & 73 & & 80.5 & $<1 \times 10^{-10}$ \\
\hline Toxoplasma gondii & 25.0 & $3 \times 10^{-5}$ & 43 & & 38 & 0.003 \\
\hline Treponema pallidum & 1.3 & & 3 & & 0 & \\
\hline Trichomonas vaginalis & 15.0 & $2 \times 10^{-8}$ & 35 & & 33 & $4.6 \times 10^{-7}$ \\
\hline Trypanosoma cruzi & 14.0 & $<1 \times 10^{-10}$ & 36 & & 31 & $9.6 \times 10^{-7}$ \\
\hline
\end{tabular}

Frequency of non-virus microbial proteins mimicking T cell receptors (TCR) are from the same sets described in Table 1. Bolded material indicates the bacteria and protozoa that mimic TCR on average more than $30 \%$ of the time. Statistics are reported only for significant differences $(p<0.001$ by $\chi$ squared with Bonferroni correction for the multiple microbes tested). See [3] for additional data.

Figure 2 provides representative data showing similarities between HIV TCR and HIV proteins. Rates of similarity were determined for each of the essential HIV proteins and these rates were used to generate Table 3. Figure 2 also shows that multiple HIV proteins often mimic any given TCR sequence. 


\section{CASSERGTNSPL}

Q8Q7H1 (Q8Q7H1_9HIV1)

Envelope glycoprotein gp160 OS=HIV1

Query 3 SSERGTNSPL 12

Sbjct 136 SSEKATSSPL 145

\section{E2GLT3 (E2GLT3_9HIV1)}

Envelope glycoprotein gp160 (Fragment)

OS=Human immunodeficiency virus 1

$\begin{array}{lll}\text { Query } 5 & \begin{array}{l}\text { ERGTNSPL } \\ + \text { RGT+SPL }\end{array} & 12\end{array}$

Sbjet 740 DRGTSSPL 747

AOA0N7EJ57 (AOAON7EJ57_9HIV1)

Gag polyprotein OS=HIV 1

Query 1 CASSERGTNS 10

Sbjet 122 CAAADRGNNS 131

\section{V5KC47 (V5KC47_9HIV1)}

Polymerase (Fragment) OS=HIV

Query 6 RGTNSP 11

Sbjet 29 RGTNSP 34

\section{A4KCX0 (A4KCX0_9HIV1) \\ Pol protein (Fragment) OS=HIV1 \\ Query 7 GTNSPL 12 \\ GTNSPI \\ Sbjet 20 GTNSPL 25}

\section{D7S1P2 (D7S1P2_9HIV1)}

Envelope glycoprotein gp160 OS=HIV

\begin{tabular}{|c|c|c|}
\hline Query & 7 & $\begin{array}{l}\text { GTNSPL } \\
\text { GTNSPI }\end{array}$ \\
\hline Sbjct & 395 & GTNSPL \\
\hline
\end{tabular}

\section{CASSGDSRDEQF}

Q4A3N3 (Q4A3N3_9HIV1) -

Protein Rev OS=HIV1

Query 4 SGDSRDEQ 11

Sbjet 5 SGDSSDEQ 12

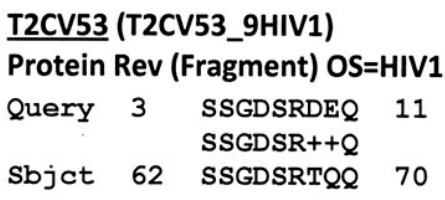

AOAOH3V2J8 (AOAOH3V2J8_9HIV1) -

Protein Rev OS=HIV1

Query 4 SGDSRD 9

Sbjet 5 SGDSRD 10

\section{C3SAQ7 (C3SAQ7_9HIV1) B2CJN3}

(B2CJN3_9HIV1)

Envelope glycoprotein (Fragment) HIV1

Query 3 SSGDSRDEQF 12

$\begin{array}{llll} & & \text { SS DSR+E F } \\ \text { Sbjet } 237 & \text { SSNDSRNETF } & 246\end{array}$

Q2VAK3 (Q2VAK3_9HIV1)

Envelope glycoprotein gp160 OS=HIV1

$\begin{array}{llll}\text { Query } & 4 & \text { SGDSRDEQ } & 11 \\ \text { Sbjct } & 138 & \text { S DSRDE+ } & \\ \text { SSDSRDEE } & 145\end{array}$

\section{CASSLELAKNI}

Q9WGU2 (Q9WGU2_9HIV1)

Polyprotein (Fragment) OS=HIV1

Query 5 LELAKN 10

Sbjet 225 LELAKN

E9JDS5 (E9JDS5_9HIV1)

Reverse transcriptase (Fragment) OS=Human

immunodeficiency virus 1

$\begin{array}{llll}\text { Query } & 5 & \text { LELAKN } & 10 \\ & & \text { LELAKN } & \\ \text { Sbjct } & 179 & \text { LELAKN } & 184\end{array}$

\section{AOAOH5BLW5 (AOAOH5BLW5_9HIV1)}

Gag-pol polyprotein (Fragment) OS=HIV-1

Query 5 LELAKN 10

Sbjet 421 LELAKN 426

Figure 2. Typical selection of HIV TCR-HIV protein similarities (BLAST 2.0 search, virus database, $E=1000$, no gaps). Accession numbers are for the UniProt protein database (www.expasy.org). See Table 3 for aggregate data for all 600 TCR examined. 
Table 3. Frequency with which HIV TCR mimic HIV proteins. See Figure 2 for examples.

\begin{tabular}{|c|c|c|c|c|c|}
\hline HIV-1 Proteins & $\begin{array}{l}\% \text { TCR } \\
\text { Normal } \\
\text { Mimics }\end{array}$ & $\begin{array}{l}\% \text { TCR } \\
\text { Control } \\
\text { Mimics }\end{array}$ & $\begin{array}{c}\% \text { TCR } \\
\text { Antisense } \\
\text { Control } \\
\text { Mimics }\end{array}$ & $\begin{array}{c}\% \text { TCR } \\
\text { Random } \\
\text { Sequence } \\
\text { Mimics }\end{array}$ & $\begin{array}{c}\% \text { TCR } \\
\text { HIV } \\
\text { Mimics }\end{array}$ \\
\hline Env (envelope proteins, gp160, gp120, gp41) & 70 & 63 & 27 & 40 & 69 \\
\hline $\begin{array}{l}\text { Pol (reverse transcriptase, protease, } \\
\text { RNAase, integrase) }\end{array}$ & 30 & 20 & 22 & 21 & 20 \\
\hline Vif (regulatory: virion infectivity factor) & 2 & 4 & 8 & 7 & 0 \\
\hline Vpu (regulatory: viral protein U, virus assembly) & 3 & 3 & 1 & 6 & 3 \\
\hline Tat (regulatory: transactivator of RNA transcription) & 5 & 2 & 6 & 4 & 0 \\
\hline Rev (regulatory: stimulates protein production) & 7 & 2 & 9 & 6 & 13 \\
\hline $\begin{array}{l}\text { Vpr (regulatory: viral protein } \mathrm{R} \text {, protein } \\
\text { production accelerator) }\end{array}$ & 0 & 1 & 3 & 3 & 3 \\
\hline
\end{tabular}

Table 3 summarizes data demonstrating that the TCR mimicry encompasses all major HIV antigens, although at very different rates. HIV envelope protein (gp160) is the most likely to mimic host TCR, which is in keeping with the very high rate of mutation of gp160. A few HIV proteins, such as Vif, Vpu and Vpx rarely show similarity to human TCR.

Figure 3 provides representative (but highly selected) data demonstrating that HIV TCR mimic human proteins with great fidelity. Human protein similarities were previously reported for all of the other human TCR utilized in this study [3]. In this instance, every HIV TCR mimicked at least one, and sometimes several dozen, human proteins. Some of these human mimics include other TCR and a variety of immunoglobulins. These immune system mimics accounted for about a third of the similarities found (see Table 4).

Table 5 displays the sequences of HIV TCR that were synthesized and used to explore whether these were similar enough to HIV itself to permit recognition by antibodies against specific HIV proteins. Table 6 summarizes the results of the quantitative ELISA experiments using the TCR sequences from Table 5; representative data from these experiments are shown in Figures 4 and 5 . Half of the TCR-HIV antibody combinations yielded measurable binding constants ranging between $1 \times 10^{-7}$ to $2 \times 10^{-9} \mathrm{M}$. The rest of the combinations were deemed to be negative, since binding constants were either greater than $1 \times 10^{-6}$ or no evidence of binding was obtained. (For reference, the association constant of insulin antibody for insulin, which is a primary cause of type 1 diabetes mellitus, is about $1 \times 10^{-8}$ [55,56], whereas healthy human beings and cats have naturally circulating anti-insulin binding that binds in the range of $1 \times 10^{-5}$ and has no clinical effect [57]). Rabbit anti-M. tuberculosis antiserum also bound measurably to some of the TCR, but a guinea-pig anti-mycobacterial antiserum did not, suggesting some specificity in both the TCR and antibody involved in the binding combinations. No significant binding was observed between cytomegalovirus or hepatitis $C$ virus antibodies and the TCR tested here. 
1 NP95-73 CASSEELAGGSYNE

20 BLAST matches at $\mathrm{E}=10 ; 0 \mathrm{TCR} / \mathrm{Ig}$

B7Z1C7 cDNA FLJ59451, highly similar to Scaffold attachment factor $B$

$\begin{array}{llll}\text { Query } 2 & \text { ASSEELA } & \\ & & \text { ASSEELA }\end{array}$

Sbjet 129 ASSEELA 135

B7ZLP5 SAFB protein OS

Query 2 ASSEELA 8

Sbjet 330 ASSEELA 336

H3BLX4 Zinc finger protein 462 (Fragment)

\begin{tabular}{llll}
\hline Query & 3 & SSEELAG & 9 \\
Sbjct & 302 & SSEELAG & \\
SSEELAG & 308
\end{tabular}

Q9NRC6 Spectrin beta chain, non-erythrocytic 5 .

Query 2 ASSEELA 8

Sbjet 3337 ASSEELA 3343

O95721 Synaptosomal-associated protein 29 .

$\begin{array}{llll}\text { Query } & 2 & \text { ASSEELA } & 8 \\ & & \text { ASSEELA } & \\ \text { Sbjct } & 76 & \text { ASSEELA } & 82\end{array}$

2 NP95-184-O CASSERGTNSPL

27 BLAST matches at $\mathrm{E}=10$; 0 TCR/Ig

K7EPU6 Putative oxidoreductase GLYR1

\begin{tabular}{lll}
\hline Query 3 & $\begin{array}{l}\text { SSERGTNSPL } \\
\text { SSERG++SPL }\end{array}$ & 12
\end{tabular}

Sbjet 53 SSERGSKSPL 62

D3DUE7 Cytokine-like nuclear factor n-pac, isoform CRA_a

Query 3 SSERGTNSPL 12

Sbjet 173 SSERGSKSPL 182

\section{NP95-184-O CASSGDSRDEQF}

4 BLAST matches at $\mathrm{E}=10 ; 0 \mathrm{TCR} / \mathrm{Ig}$

Q6NS94 CYLC1 protein (Fragment)

Query 2 ASSGDSRDE 10

A+SGDS+DE

Sbjet 334 AESGDSKDE 342
Q9GZX5 Zinc finger protein $350^{\circ}$

Query 1 CASSGDSR 8

- Sbjet 494 CAASGDNR 501

4 NP95-73 CASSLELAKNI

13 BLAST matches at $\mathrm{E}=10 / 0 \mathrm{TCR} / \mathrm{Ig}$

Q9H8E5 cDNA FLJ13705 fis, clone

PLACE2000302

$\begin{array}{llll}\text { Query } 2 & \text { ASSLELAKNI } 11 \\ & & \text { ASSLELAK I }\end{array}$

Sbjet 143 ASSLELAKGI 152

B7Z8Y3 cDNA FLJ61696, highly similar to Double-stranded RNA-specific adenosine deaminase (EC 3.5.4.-)

Query 3 SSLELAKNI 11

$\begin{array}{lll} & \text { S L+ILAKNI } \\ \text { Sbjet } 314 & \text { SALNLAKNI } 322\end{array}$

Q59EC0 Adenosine deaminase, RNA-specific isoform ADAR-a variant

Query 3 SSLELAKNI 11

$\begin{array}{llll} & \text { S L+LAKNI } \\ \text { Sbjet } 332 & \text { SALNLAKNI } & 340\end{array}$

\section{NP89-213 CASSLVGLRGNTEA}

7 BLAST matches at $\mathrm{E}=10$; 1 TCR

$\underline{P 04435}$ T-cell receptor beta chain $V$ region CTL-

L17

$\begin{array}{llll}\text { Query } & 1 & \text { CASSLVGL } & 8 \\ \text { Sbjet } & 111 & \text { CASSL+GL } & \\ \text { CASSLAGL } & 118\end{array}$

Q6P5R1 TMEM59 protein (Fragment)

$\begin{array}{llll}\text { Query } 2 \text { ASSLVGLRGNTE } & 13 \\ & \text { ASSLV +R +TE }\end{array}$

Sbjet 209 ASSLVVVRSKTE 220

A4D250 (BLACE_HUMAN) B-cell acute lymphoblastic leukemia-expressed protein

$\begin{array}{llll}\text { Query } & 3 & \text { SSLVGLRGN } & 11 \\ \text { SSjjct } & 129 & \text { SSL+LALRGN } & 137\end{array}$

Figure 3. Selected examples of HIV TCR-Human protein similarities (BLAST search, $E=10$, no gaps). See Figure 6 for examples. Accession numbers refer to the UniProt protein database (www.expasy.org).

Table 4. Frequency with which HIV TCR mimic human proteins (see Figure 3 for examples). The number of matches is provided plus or minus the standard deviation for total human protein similarities; for the subset of other TCR and immunoglobulins; and for the subset of somatic proteins.

\begin{tabular}{ccc}
\hline $\begin{array}{c}\text { Average Total BLAST Human } \\
\text { Similarities per HIV TCR }\end{array}$ & $\begin{array}{c}\text { Average HIV TCR Similarities to } \\
\text { Other Human TCR/Ig per HIV TCR }\end{array}$ & $\begin{array}{c}\text { Average Non-TCR/Ig Human } \\
\text { Similarities per HIV TCR }\end{array}$ \\
\hline $28.5 \pm 19.0$ & $10.7 \pm 10.7$ & $17.5 \pm 16.5$ \\
\hline
\end{tabular}


Table 5. List of TCR sequences from HIV patients synthesized for use in ELISA experiments (randomly selected from Lin et al., 2005 [58]).

\begin{tabular}{ccc}
\hline TCR ID & Sequence & Patient \\
\hline HIV 1 & CASSEELAGGSYNE & NP95-73 \\
HIV 2 & CASSERGTNSPL & NP95-184-O \\
HIV 3 & CASSLELAKNI & NP95-184-O \\
HIV 4 & CASSGDSRDEQFF & NP95-73 \\
HIV 5 & CASSLWVTGGEQFF & NP89-213 \\
HIV 6 & CASSFSSGRPGELF & NP95-73 \\
HIV 7 & CASSLTVSSYNEQ & NP95-73 \\
HIV 8 & RCASSSGANV & NP95-73 \\
HIV 9 & FCASRFERELGQPQ & NP-94-34 \\
HIV 10 & LCSVVTGDGYTF & NP95-184-O \\
HIV 11 11 & CASSLVGLRGNTEA & NP89-213 \\
HIV 12 & CASSLASYTEA & NP94-34 \\
\hline
\end{tabular}

Table 6. Results of quantitative ELISA experiments (see Figures 4 and 5 for examples of data) between HIV-antibodies and TCR from HIV-infected patients (see Table 3).

\begin{tabular}{|c|c|c|c|c|c|c|c|c|c|c|c|c|}
\hline & HIV-1 & HIV-2 & HIV-3 & HIV-4 & HIV-5 & HIV-6 & HIV-7 & HIV-8 & HIV-9 & HIV-10 & HIV-11 & HIV-12 \\
\hline $\begin{array}{l}\text { HIV-1 gp120 } \\
\left(\times 10^{-6}\right)\end{array}$ & 0.0024 & $>1$ & 0.014 & 0.016 & $>1$ & 0.018 & $>1$ & $>1$ & $>1$ & $>1$ & 0.10 & 0.055 \\
\hline $\begin{array}{l}\text { HIV-1 Pol } \\
\left(\times 10^{-6}\right)\end{array}$ & 0.017 & 0.012 & 0.0081 & $>1$ & $>1$ & $>1$ & $>1$ & 0.036 & $>1$ & 0.028 & 0.025 & 0.0085 \\
\hline $\begin{array}{l}\text { HIV-1 Gag } \\
\text { P24 }\left(\times 10^{-6}\right)\end{array}$ & 0.052 & $>1$ & $>1$ & $>1$ & $>1$ & $>1$ & $>1$ & 0.078 & 0.08 & $>1$ & $>1$ & $>1$ \\
\hline $\begin{array}{l}\text { HIV-1 Gag } \\
\text { P17 }\left(\times 10^{-6}\right)\end{array}$ & 0.022 & 0.018 & 0.010 & $>1$ & $>1$ & $>1$ & $>1$ & $>1$ & $>1$ & $>1$ & $>1$ & $>1$ \\
\hline $\begin{array}{l}\text { HIV-1 Tat } \\
\left(\times 10^{-6}\right)\end{array}$ & $>1$ & $>1$ & 0.028 & $>1$ & $>1$ & $>1$ & 0.020 & 0.034 & 0.022 & $>1$ & $>1$ & 0.015 \\
\hline $\begin{array}{l}\text { HIV-1 Nef } \\
\left(\times 10^{-6}\right)\end{array}$ & 0.031 & $>1$ & $>1$ & $>1$ & 0.0037 & $>1$ & 0.011 & 0.033 & $>1$ & 0.024 & 0.072 & 0.0085 \\
\hline $\begin{array}{l}\text { CMV (AD169) } \\
\text { Mab }\left(\times 10^{-6}\right)\end{array}$ & & & & & & & & $>1$ & $>1$ & $>1$ & & \\
\hline $\begin{array}{c}\text { HCV Core } \\
\left(\times 10^{-6}\right)\end{array}$ & $>1$ & $>1$ & $>1$ & $>1$ & $>1$ & $>1$ & $>1$ & $>1$ & $>1$ & $>1$ & $>1$ & $>1$ \\
\hline $\begin{array}{l}\text { RBT M. tuber. } \\
\qquad\left(\times 10^{-6}\right)\end{array}$ & 0.011 & $>1$ & $>1$ & $>1$ & $>1$ & 0.10 & $>1$ & $>1$ & 0.0085 & $>0.1$ & $>1$ & $>1$ \\
\hline $\begin{array}{c}\text { Anti-Mycob. } \\
\left(\times 10^{-6}\right)\end{array}$ & $>1$ & $>1$ & $>1$ & $>1$ & $>1$ & $>1$ & $>1$ & $>1$ & $>1$ & $>1$ & $>1$ & $>1$ \\
\hline
\end{tabular}

Binding constants highlighted in black are in the range of $10^{-9} \mathrm{M}$; highlighted in medium grey are in the range of $10^{-8} \mathrm{M}$; highlighted in light grey are in the range of $10^{-7}$; and those with white backgrounds had binding constants above $10^{-6} \mathrm{M}$. CMV = cytomegalovirus; $\mathrm{HCV}=$ hepatitis $\mathrm{C}$ virus; $\mathrm{M}$. tuber. $=$ Mycobacterium tuberculosis; anti-mycobacterium is a polyclonal antibody against mycobacteria species in general.

The main limitation of these Results is that the ELISA results that TCR peptides can bind to anti-HIV antibodies are not enough to conclude that these antibodies really recognize and bind to TCR in physiological situations. It remains to be determined whether HIV antibodies (particularly antilymphocytic autoantibodies) from people with AIDS actually bind to TCR/CD3 complexes expressed on T cells. Evidence that T cells are targeted in AIDS will be presented in the Discussion below, as will evidence that anti-HIV antibodies target specific targets in the microbiome. 
TCR PEPTIDES BINDING HIV-1 TAT ANTIBODY

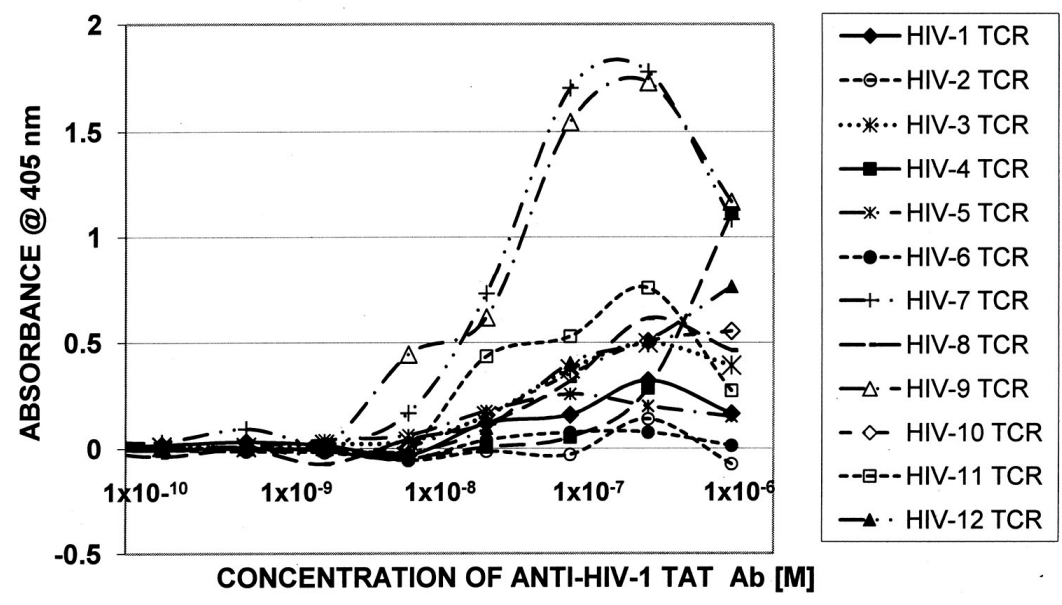

Figure 4. Quantitative ELISA experiments between rabbit anti-HIV-1 Tat antibody and the TCR sequences listed in Figure 2.

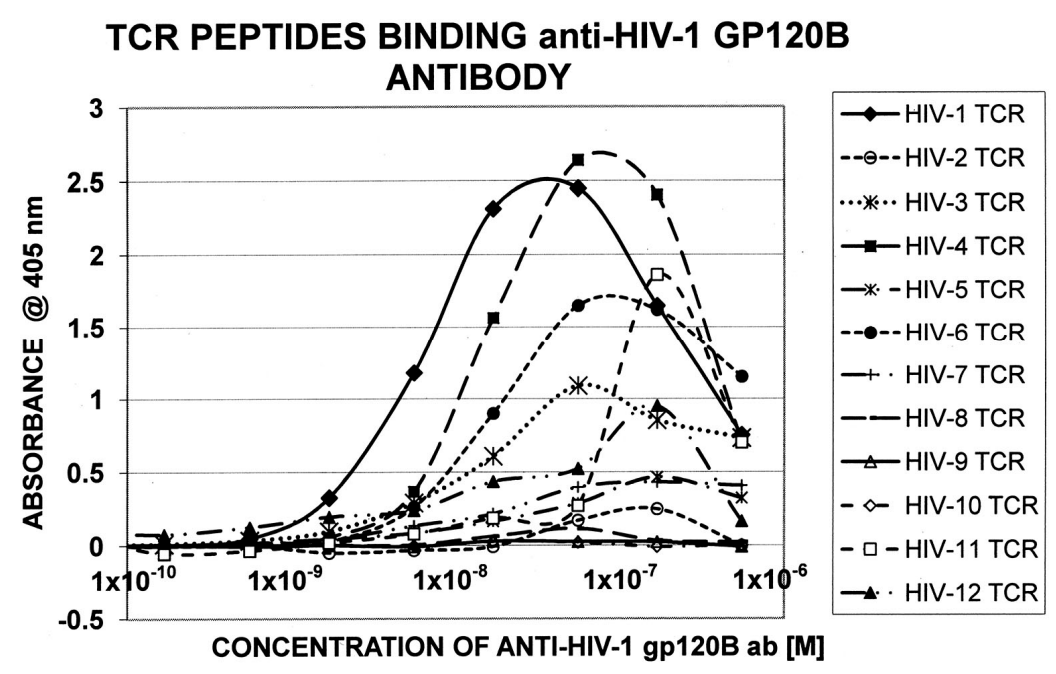

Figure 5. Quantitative ELISA experiments between goat anti-HIV-1 gp120B antibody and the TCR sequences listed in Figure 2.

\section{A Summary Model for HIV-Host-Microbiome Holoimmunity}

Figure 6 summarizes the foregoing results as an integrated mechanistic model. The immune system, in this case represented by TCR, develops to create a "body double" of the host by mimicking host antigens. Anything that can interact with this immnunological "body double" (which is to say, anything that is molecularly complementary to it) activates an immune response to block adverse interactions with the rest of the host. Through this vetting process, the host microbiome is selected for its characteristic of mimicking the host and its immunological "body double". Such mimicry protects the microbiome constituents from immune surveillance. Thus, commensal and symbiotic constituents of the microbiome are found to mimic human TCR to a far greater degree than are pathogens. The evolution of such mimicry is probably driven by selection pressures on microbes to camouflage themselves from the immune system by looking like it, while the immune system itself has probably evolved to protect the host by mimicking key host proteins so that any microbe or toxin that can interact with these proteins will be intercepted by antibodies or TCR first. 


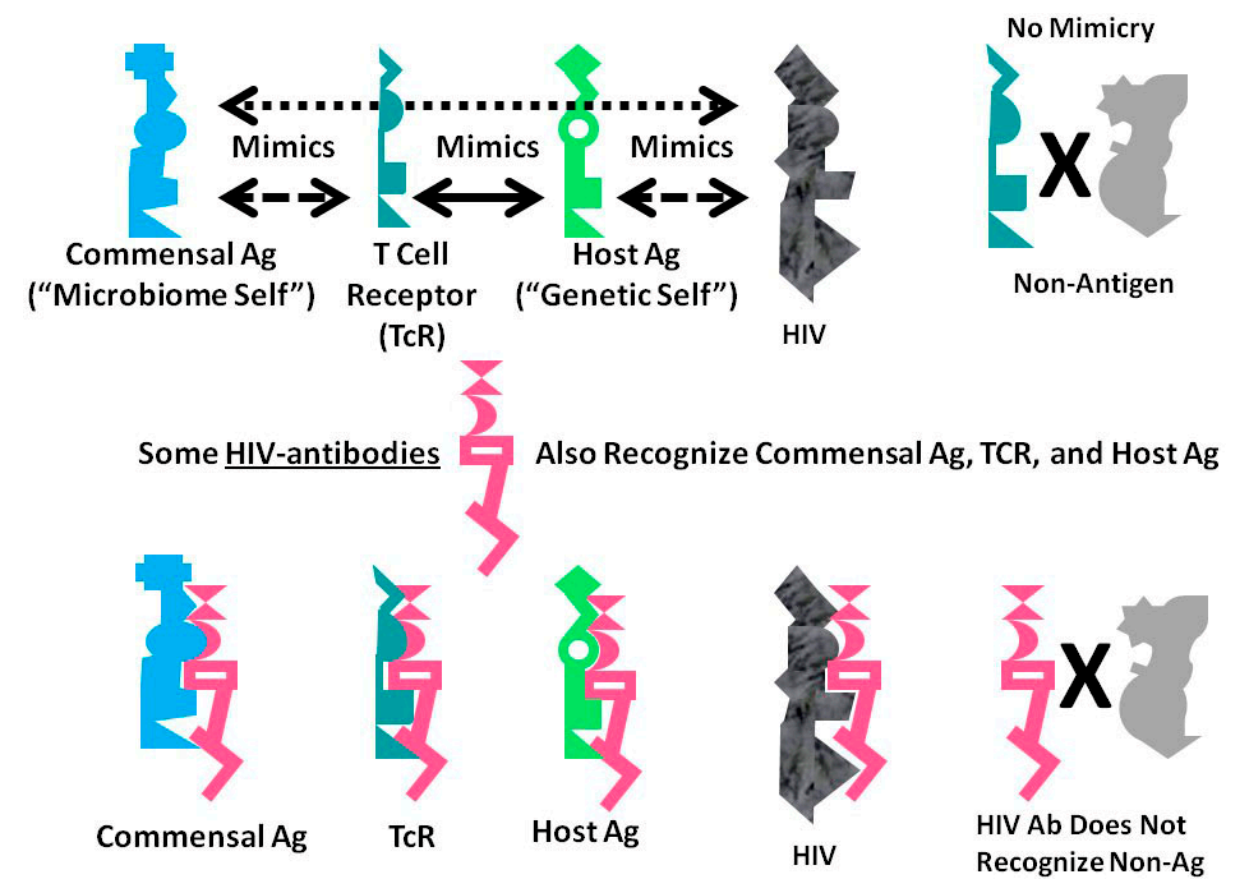

Figure 6. Graphical abstract of the results reported here demonstrating the range of consequences that result from the fact that HIV antigens mimic human TCR. Previous research [3-7] has demonstrated that human TCR mimic host proteins and the host microbiome. It has been proposed that the microbiome is selected for its compatibility with the host immune system by camouflaging itself through such molecular mimicry. This process has led to the proposal that the immune system not only mediates genetic "self", but also the integrated holobiont "self" composed of the host and its microbiome. The data reported here strongly supports the contention that HIV mimics all components of the holobiont including, host TCR, host proteins and microbiome proteins. In order for the host immune system to eliminate HIV, it is, therefore, very likely that it will have to attack its own T cells, some of its tissues and specific components of the host microbiome. Thus, the mechanism proposed here suggests how an HIV infection, by altering specific elements of self-tolerance, may also alter tolerance for particular components of the microbiome producing some of the gut and skin symptoms commonly seen in people with AIDS. In sum, the production of lymphotcytotoxic autoantibodies in AIDS due to HIV-mimicry of host TCR should also induce autoimmunity not only against TCR, but a wider autoholoimmunity against the holobiont microbiome as well.

The data presented here demonstrate that HIV mimics TCR as well as host proteins and microbiome proteins and does so to a greater degree than any other class of microbes tested other than commensal Bacteroides species. These data suggest that HIV is itself evolving into a commensal organism for its human host and helps to explain the difficulty that people actively infected with HIV have in controlling their HIV infection.

A consequence of these multiple forms of mimicry is that production of antibodies against HIV will produce antibodies that also recognize TCR (i.e., act like lymphocytotoxic autoantibodies) and that cross-react with some microbiome proteins as well. Thus, breaking tolerance to HIV will almost necessarily lead to breaking tolerance against elements "self" and the host's microbiome. The resulting immune response will target host TCR (antilymphocyte autoimmunity) thereby reducing the ability of the immune system to respond to the pathogens such TCR would normally control. HIV mimicry of the host microbiome seems to correlate with microbial species that cause opportunistic infections in AIDS. Thus, autoimmunity against TCR initiated by HIV may result in specific "holes" in the TCR network necessary to control such infections. 


\section{Discussion}

To summarize the experimental results, HIV mimics human TCR at a far higher rate than any other microbe thus far examined. In context, this finding strongly suggests that if HIV is not already a commensal organism for human beings, it is well on its way, just as simian immunodeficiency virus (SIV) is commensal for some monkey species $[59,60]$. The support for this conclusion is that previous research has demonstrated that the more similarities a microbe has to the TCR repertoire of a host organism, the greater the probability is that this microbe is a commensal organism or symbiont for its host [3-7]. Indeed, in this study, it is demonstrated that chronic and latent viruses such as hepatitis, cytomegalovirus and papilloma are far more likely to mimic host TCR sequences than are acutely infectious viruses. Commensal gut bacteria such as Bacteroides, Clostridia and Lactobacilli are the only microbes with rates of TCR similarity that are even close to that displayed by HIV. The similarity of HIV for host proteins extends significantly beyond TCR sequences as well: Lucchese et al. [61] found that at the pentapeptide level, the HIV-human proteome overlap consists of 14,227 matches disseminated throughout 10,312 human proteins. HIV, in short, is very well camouflaged from immunological surveillance at the molecular level.

The mimicry of human HIV-associated TCR for HIV itself was confirmed using quantitative ELISA. All of the polyclonal HIV antibodies tested recognized one or more human TCR, and six of the interactions were certainly strong enough to provoke an active autoimmune response and so may represent lymphocytotoxic autoantibodies. The shift from a Th1 to a Th2 immune response to HIV that often signals a transition to the development of AIDS may therefore require overriding tolerance mechanisms and thus, necessarily induces autoimmunity. Cytomegalovirus, hepatitis $C$ and tuberculosis antibodies did not show either as broad or as high-affinity interactions with the same TCR indicating that the HIV mimicry of human TCR is relatively unique to this virus.

The data also demonstrate that all TCR are strongly selected to mimic the human proteome itself $[3,4]$. Indeed, approximately 15 to 20 percent of TCR sequences are widely shared among diverse individuals as "public" sequences [62-64] so that the actual proteins mimicked by TCR are probably highly conserved from one individual to another. Williams et al. [65] have demonstrated, for example, that anti-HIV gp41 antibodies recognize a range of human proteins, and that the interaction between these antibodies and host proteins prevents neutralization of HIV by adsorbing significant amounts of antibody.

The potential for autoimmunity following HIV antibody production may extend beyond TCR as targets. Rolland et al. [66] have demonstrated experimentally that $\mathrm{T}$ cell recognition of HIV antigens is inversely related to the degree to which they mimic human proteins in general: the more similar an HIV antigen is to a human antigen, the more likely it will be tolerated as "self". In light of recent observations that TCR mediate tolerance between both the human proteome and the microbiome by means of just such similarities [3-6], it seems likely that HIV has evolved very effectively to camouflage itself by mimicking not only a wide range of human proteins, but also, through its mimicry of both HLA and TCR proteins, the human immune system itself. These results are also consistent with HIV being closely related to class K human endogenous retroviruses [63-69]. Additionally, this hypothesis is also consistent with SIV being non-pathogenic in some monkey species due a T-cell-mediated mechanism [59,60]. In short, HIV may have evolved, or is in the process of evolving, into a commensal organism that is only pathogenic under extraordinary conditions of immunological dysfunction.

An important consequence of the concept of holoimmunity is that the same immunological mechanisms that determine "self"-"nonself" also operate to regulate what microbes can participate as non-pathogenic components of the host microbiome. Microbiome microbes mimic host antigens. Thus, HIV mimicry of its host will, according to holoimmunity, also result in mimicry of microbiome constituents. This appears to be the case. Notably, TCR mimicking HIV also mimic particular components of the human microbiome, in particular those microbes most associated with AIDS-related infections. This result suggests that the shift in HIV-related TCR shifts the immune system's tolerance (or intolerance) for the diseases that develop during AIDS, especially the opportunistic gut infections 
that occur in many people with AIDS such as pathogenic Chlostridia, Enterobacteria, Enterococci, and Giardia. TCR mimicry also significantly increases to other microbes such as Mycobacteria, Staphylococci, Streptococci, and Trichomonas, which are common concomitants of AIDS. The increase of TCR mimicry of these microbes suggests an attempt by the immune system to mediate disease, as well as selection by the microbiome during AIDS development toward microbes that increasingly avoid immune detection through mimicry [3-6]. Williams et al. [65] and Trama et al. [70] have, indeed, reported significant cross-reactivity between antibodies against HIV and commensal bacteria as well as diversion of HIV-vaccine-related antibodies from HIV to these microbiome microbes. More specifically, they found that $82 \%$ of anti-HIV gp 41 antibodies cross-reacted specifically with commensal gut bacteria, just as would be expected from the TCR data provided here.

An unusual prediction that follows from mutual HIV-TCR-host-microbiome mimicry is that risk of HIV infection may be mediated by the microbiome itself. One of the holoimmunity principles stated by Root-Bernstein [3] is that, because the microbiome has evolved to mimic the host and more specifically host TCR, the microbiome functions in part as a secondary immune system that can recognize and defend against the same antigens that are recognized by TCR. A healthy microbiome should therefore be a robust defense against HIV infection. One of the best-characterized instances of such a protective effect is seen in the relationship between vaginal microbiome health and risk of HIV acquisition in women. A healthy vaginal microbiome, dominated by normal Lactobacilli, reduces HIV and sexually transmitted infections among African women [71,72], while vaginal dysbiosis results in production of HIV-enhancing factors and increased HIV risk [73,74]. Prophylactic use of Lactobacilli introduced into the vagina has resulted in lowered risk of HIV and herpes simplex virus acquisition in women with dysbiosis $[75,76]$. The results of HIV-TCR-microbiome similarities found here, however, taken in conjunction with the results of Trama et al. [70], Petrova et al. [77], and Williams et al. [65] concerning HIV cross-reactivity with many commensal microbes, suggest that microbiome-HIV interactions are mediated by many microbes in addition to Lactobacilli. Thus, a broader microbiome approach may be required to effectively mediate HIV infection.

These results have important implications for understanding HIV pathogenesis even beyond how the microbiome mediates HIV infection and what co-infections the immune system can recognize as HIV infection progresses. One additional implication is that anti-HIV and anti-lymphocyte autoimmunity are integrally related aspects of AIDS [10-20,26-34,78-81]. Indeed, Kion and Hoffman demonstrated that it is possible to produce an animal model of AIDS using lymphocytes as antigens; the resulting autoimmune process not only destroys T cells but is also cross-reactive with HIV [80,81]. These results can be explained by the very striking antigenic similarities between TCR and HIV revealed here, especially if one considers the Hoffmann-Kion model as a form of autoholoimmunity that can be initiated by either host or microbial mimics.

Another important implication of the data reported here is to explain the almost universal finding of anti-T cell autoimmunity in people with AIDS [15,16,26,29-34]. The switch from Th1 to Th2 immunity that characterizes the development of HIV into AIDS is almost always accompanied by the production of lymphocytotoxic autoantibodies (LCTA). In light of the mimicry of HIV for TCR, LCTA would be an almost unavoidable consequence of developing active Th2-mediated immunity to HIV as almost any anti-HIV antibody will cross-react with some subset of TCR. Antibody against HIV will therefore induce $\mathrm{T}$ cell destruction as a by-product, making autoimmunity an integral part of AIDS pathogenesis $[15,16]$. One consequence of this HIV-induced intra-system autoimmunity is inflammation within the lymphatic system itself, leading to deposition of fibrotic tissue. This inflammatory process is inversely proportional to T cell count [82]. Thus, once again, AIDS can be considered a form of autoholoimmunity.

There are also treatment implications of the mimicry of HIV for TCR. First, given that about seventy percent of randomly selected TCR sequences in normal human beings, and up to ninety percent in HIV-infected individuals mimic HIV proteins, it is extremely unlikely that it will be possible to produce a whole-virus HIV vaccine that does not mimic host TCR to a very significant degree. 
Such vaccines will either be treated immunologically as "self" and therefore fail to induce immunity or, if the immune system can be tricked into being activated, the response will cross-react with one or more subsets of TCR, therefore causing the very T cell destruction that the vaccine is intended to avoid. The repeated failure of HIV vaccines, and particularly of gp160 (envelope protein)-based vaccines (which have the highest similarity to TCR) is a matter of record [83-85]. In addition, the induction of anti-T cell autoimmunity has, been reported in some failed trials, with concomitant enhancement of HIV acquisition [86-88]. In fact, components of the envelope protein are actively tolerized by the human immune system [89] so that HIV-infected patients who do develop broadly neutralizing antibodies that can target multiple HIV strains also produce high levels of autoantibodies and low levels of regulatory T cells [90]. All of these results follow logically from the observation of HIV-TCR-human proteome mimicry reported here.

Alternative approaches to developing HIV vaccines, such as Gag/Pol/Nef vaccines, have also failed [91], perhaps because these antigens are not readily recognized by antibodies, but also perhaps because the target proteins, like envelope protein-based vaccines, also mimic host antigens and TCR sequences. The data presented here suggest that the best components from which to construct an HIV vaccine that would be recognized as clearly "non-self" and have minimal cross-reactivity with human lymphocytes will be those proteins that have the least similarity to host TCR, which means the HIV regulatory proteins Tat, Rev, Vif, Vpu and Vpx (Tables 4 and 5). Unfortunately, these proteins are not displayed in the native virus, are generally inaccessible to antibody, and are therefore likely to be ineffective as components of vaccines.

In light of HIV mimicry of both HLA and TCR, rather than attempting to vaccinate against HIV directly, some investigators have argued that alloimmunization appears may be more effective approach to treating existing HIV infection to reestablish tolerance $[83,92,93]$. Another possibility might be to utilize a virus sufficiently similar to HIV to cross-react with it, but sufficiently unadapted to human beings to be recognized as "non-self" and therefore to activate a robust antibody response that does not cross-react with TCR. One such possibility might be simian immunodeficiency virus (SIV) [94], which did not show up as a TCR mimic in the homology searches conducted here.

\section{Methods}

\subsection{Proteonomics}

The results reported here are an unexpected product of a study of TCR mimicry related to tolerance for the human microbiome [3] That study employing 520 published CD3 V- $\beta$-D-J- $\beta$ regions from peripheral blood human TCR derived from normal control patients, people with various monoinfections (such as influenza, HTLV, Streptococcus type A, and tuberculosis), and the antisense versions of these monoinfection TCR. In addition, TCR from people with two autoimmune diseases (Crohn's and type 1 diabetes mellitus) were explored for similarities to human self-proteins and microbiome antigens [references and all sequences available in [3]. An additional 109 TCR sequenced from people with AIDS were added to the present study (see Supplementary Material). These TCR were acquired from the following sources: [58,95-97]. Finally, two sets of control TCR were utilized in this study. The first was a set of 101 "antisense TCR" sequences generated from 101 normal patient control TCR by using theses sequences to predict their complementary or "antisense" sequences (see [3] for details and sequences). An additional 100 random TCR-like sequences of 15 amino acids in length (the average length of the TCR used in this study) were generated using a random peptide sequence generator (http: / / web.expasy.org/randseq/) —see Supplementary Material for sequences. The antisense and random TCR results were aggregated to provide a robust control of 201 variously randomized TCR-like sequences with which to compare the patient-selected TCR results.

Similarity searching of proteonomic databases provided the probabilities that any given TCR would be mimicked by a protein in any given species or genera of microbes. Data on mimicry was obtained by using each TCR sequence as a search string in a BLAST 2.0 search (www.expasy.org) with 
the $E$ value set to 1000 with 1000 sequences displayed and the gapped sequence feature turned off. The results were hand-curated for human pathogens, commensal and symbiotic microbes after separate searches of the entire UniProtKB, bacterial and viral databases. Mimicry was defined, for the purposes of this study, as having at least six identical amino acids in a sequence of ten. This criterion was employed because various studies have demonstrated that this degree of similarity is often sufficient to result in antibody cross-reactivity between peptides [98-101]. Moreover, similar criteria have been used in previously published HIV-mimicry studies (e.g., [23,61,83]. For example, Lucchese et al. [61], compared the amino acid primary sequence of HIV-1, isolate CDC-451 with the human proteome and found that HIV-1 shares 50 heptapeptides and three octapeptides with the human proteome, of which 34 are experimentally validated epitopes targeted by immune responses following HIV-1 infection. It has previously been demonstrated that the results are not significantly skewed by the number of taxons or specific protein entries in the UniProtKB database [3].

A similar BLAST 2.0 (www.expasy.org) search of the human proteome was conducted with the HIV TCR with the BLOSSUM80 algorithm, $E=10$, no gaps and the 100 best matches displayed.

\subsection{Statistics}

A $\chi$-squared test (http:/ / www.quantpsy.org/chisq/chisq.htm) was used to compare the observed frequencies of the microbial similarities to TCR. Because multiple $x$-squared tests were run on the same sets of data, a Bonferroni correction was employed (http:/ / www.winsteps.com/winman/bonferroni. $\mathrm{htm})$. With about 40 microbes in both the bacterial/protozoal list and the virus list, the Bonferroni correction to achieve the equivalent of $p<0.5$ significance was reset to $p<0.001$. Only results that met or exceeded $p<0.001$ significance are therefore reported.

\subsection{T Cell Receptor Peptide Synthesis}

A random selection of twelve TCR sequences from the HIV-positive patients (Figure 2 [58]) was synthesized by the Macromolecular Synthesis and Mass Spectrometry Facility of the Biochemistry Department of Michigan State University. These were purified using HPLC to at least $98 \%$ purity as determined by mass spectrometry.

\subsection{Antibodies}

Guinea pig anti-mycobacterium and Rabbit anti-M. tuberculosis (Biodesign, Kennebunkport, ME, USA). The following antibodies were obtained from the NIH AIDS Reagent Program, Division of AIDS, NIAID, NIH: Goat anti HIV-1 gp120 (PB1) (NIH 36) with specificity for IIIB gp120 (aa 295-474); Goat anti HIV-1 gp120 (PB1) (NIH 41) with specificity for MN and RF gp 120 (aa 295-474); Sheep anti HIV-1 p17 (NIH 286); Sheep anti HIV-1 p24 (NIH 287); Sheep anti-HIV-1 gp120 (NIH 288); Rabbit anti HIV-1 Tat (NIH 705); Mouse anti-CMV (AD 169) gB (NIH 1592); Rabbit anti HIV-1 Nef (NIH 2949); Rabbit anit HIV-1 Protease (NIH 4105); Rabbit anti HIV-1 HIV-1 p17 (NIH 4811); Rabbit anti-HIV-1 RT (NIH 6195). NIH 36 and 41 were obtained through the NIH AIDS Reagent Program, Division of AIDS, NIAID, NIH [102]. NIH 286, 287, 288 were obtained through the NIH AIDS Reagent Program, Division of AIDS, NIAID, NIH: Antiserum to HIV-1 p17 from Michael Phelan. NIH 705 was obtained through the NIH AIDS Reagent Program, Division of AIDS, NIAID, NIH: Antiserum to HIV-1 Tat from Bryan Cullen [103]. NIH 1592 was obtained through the NIH AIDS Reagent Program, Division of AIDS, NIAID, NIH: Monoclonal Antibody to CMV (AD169) gB from Lucy Rasmussen [104]. NIH 2949 was obtained through the NIH AIDS Reagent Program, Division of AIDS, NIAID, NIH: Catalog \#2949, Anti-HIV-1 Nef Polyclonal from Ronald Swanstrom [105]. NIH 4105 was obtained through the NIH AIDS Reagent Program, Division of AIDS, NIAID, NIH: Anti-HIV-1 Protease Polyclonal. NIH 4811 was obtained through the NIH AIDS Reagent Program, Division of AIDS, NIAID, NIH: Anti-HIV-1 p17 Polyclonal from Paul Spearman and Lingmei Ding. NIH 6195 was obtained through the NIH AIDS Reagent Program, Division of AIDS, NIAID, NIH. 


\subsection{ELISA}

Quantitative enzyme-linked immunoadsorption assays (ELISA) were run on the TCR peptides listed in Figure 1 against the antibodies listed above. Briefly, ten serial dilutions by thirds of a $1 \mathrm{mg} / \mathrm{mL}$ solution of each TCR were made in $\mathrm{pH} 7.4$ phosphate buffer. $100 \mu \mathrm{L}$ of each dilution was added to each well in a 96-well Costar 3590 high affinity ELISA plate and run in triplicate. The plate was incubated for one hour at room temperature and then washed three times with 2\% TWEEN 20 in phosphate buffer. Next, $200 \mu \mathrm{L}$ of a $1 \%$ polyvinylalcohol solution was added as a plate blocker to each well, incubated for 1 hour, and then washed as above. $100 \mu \mathrm{L}$ of 1:1000 primary antibody was added to each well, incubated and washed. The appropriate secondary HRP-labeled antibody (1:1000) was then added to each well, incubated and washed. Finally, $100 \mu \mathrm{L}$ of ABTS single reagent was added to each well, incubated for 30 minutes, and then read at $405 \mathrm{~nm}$ in a SpectraMax UV-Vis scanning spectrophotometer. Data were analyzed and plotted using Excel. Most of the ELISAs were run at least twice for confirmation. Only those binding curves that exceeded an absorbance value equal to or greater than 0.5 O.D. at $405 \mathrm{~nm}$ were calculated; anything below this absorbance cut-off was assumed to be non-specific binding.

\section{Conclusions}

In sum, it has been well established by previous investigators that HIV mimics many human proteins and in particular HLA, while here it is demonstrated that HIV also mimics TCR and this mimicry translates into antibody specificity for about half of the TCR that display such mimicry. Thus, an active antibody response to HIV may result in lymphocytotoxic autoantibodies directed at TCR. The immune system faced with an HIV infection is therefore faced with a difficult "decision": it may ignore the infection, risking overwhelming infection, or it may respond to the infection, potentially inducing an autoimmune response. Since immune activation requires presentation of antigen by HLA to an appropriate TCR in the presence of CD4, and HIV mimics two of the three key molecules in this process (HLA and TCR), its camouflage is doubly subversive, which may help to explain the difficulty in mounting an effective immune response to HIV.

I would like to speculate further that HIV is either already commensal in human beings or well on the way to becoming so. The import of this speculation is that HIV may not, intrinsically, be pathogenic just as other commensal organisms are not ordinarily pathogenic. In this context, it is advisable to remember that HIV is very difficult for a healthy human being to acquire. Documented rates of acquisition of HIV among healthcare providers exposed subcutaneously to HIV are in the order of 1 in 3000 exposures (which compares to 1 in 2 for hepatitis B) [106]. Healthy heterosexuals engaged in vaginal intercourse with an HIV-positive partner [107], have very low rates of seroconversion (1 in 3000 to 1 in 8000). HIV appears to require already impaired immunity or various cofactors to overcome immunological tolerance to it in order to induce active disease [15,81,108-111]. Such pre-conditions would be consistent with HIV being a commensal, or near-commensal, organism for human beings.

Other important implications also follow from the observation that HIV mimics TCR. In order to control an HIV infection, the immune system must break "self" tolerance. An unavoidable consequence of breaking self-tolerance is autoimmunity directed at the immune system itself, which may help to explain why anti-retroviral therapies have not proven sufficient to cure AIDS. Such autoimmunity can also be expected to ensue as a result of active vaccination against HIV making the development of any HIV vaccine highly problematic.

Equally importantly, the results described here suggest that an active response to HIV will also spill over to the host's microbiome, shifting tolerance for some of its components away from normal, and opening up the host to opportunistic infections. Conversely, a healthy microbiome may assist in preventing HIV acquisition and transmission. Thus, within the concept of the human being as a holobiont, the trifecta of TCR-host-microbiome similarities that is manipulated by HIV mimicry of all three results in systems-wide attacks following active infection that are best described by the concept of autoholoimmunity. 
Supplementary Materials: Supplementary materials can be found at www.mdpi.com/1422-0067/18/10/2091/s1. Acknowledgments: Karen Luplow performed many of the experiments. This research was supported by gifts from Maurine Bernstein.

Conflicts of Interest: The author declares no conflicts of interest.

\section{References}

1. Margulis, L.; Fester, R. Symbiosis as a Source of Evolutionary Innovation; MIT Press: Cambridge, MA, USA, 1991.

2. Mindell, D.P. Phylogenetic consequences of symbioses: Eukarya and Eubacteria are not monophyletic taxa. BioSystems 1992, 27, 53-62. [CrossRef]

3. Root-Bernstein, R.S. Autoimmunity and the microbiome: T-cell receptor mimicry of "self" and microbial antigens mediates self tolerance in holobionts. BioEssays 2016, 38, 1068-1083. [CrossRef] [PubMed]

4. De Groot, A.S.; Moise, L.; Liu, R.; Gutierrez, A.H.; Tassone, R.; Bailey-Kellogg, C.; Martin, W. Immune camouflage: Relevance to vaccines and human immunology. Hum. Vaccin. Immunother. 2014, 10, 3570-3575. [CrossRef] [PubMed]

5. Moise, L.; Terry, F.; Gutierrez, A.H.; Tassone, R.; Losikoff, P.; Gregory, S.H.; Bailey-Kellogg, C.; Martin, W.D.; de Groot, A.S. Smarter vaccine design will circumvent regulatory T cell-mediated evasion in chronic HIV and HCV infection. Front. Microbiol. 2014, 5, 502. [CrossRef] [PubMed]

6. Moise, L.; Beseme, S.; Tassone, R.; Liu, R.; Kibria, F.; Terry, F.; Martin, W.; de Groot, A.S. T cell epitope redundancy: Cross-conservation of the TCR face between pathogens and self and its implications for vaccines and autoimmunity. Expert Rev. Vaccines 2016, 15, 607-617. [CrossRef] [PubMed]

7. Yan, N.; Lieberman, J. Gaining a foothold: How HIV avoids innate immune recognition. Curr. Opin. Immunol. 2011, 23, 21-28. [CrossRef] [PubMed]

8. Rasaiyaah, J.; Tan, C.P.; Fletcher, A.J.; Price, A.J.; Blondeau, C.; Hilditch, L.; Jacques, D.A.; Selwood, D.L.; James, L.C.; Noursadeghi, M.; et al. HIV-1 evades innate immune recognition through specific cofactor recruitment. Nature 2013, 503, 402-405. [CrossRef] [PubMed]

9. Guha, D.; Ayyavoo, V. Innate immune evasion strategies by Human Immunodeficiency Virus Type 1. ISRN AIDS 2013, 954806. [CrossRef] [PubMed]

10. Via, C.S.; Shearer, G.M. Autoimmunity and the acquired immune deficiency syndrome. Curr. Opin. Immunol. 1989, 1, 753-756. [CrossRef]

11. Malatzky-Goshen, E.; Shoenfeld, Y. AIDS and autoimmunity. Autoimmunity 1989, 3, 201-212. [CrossRef] [PubMed]

12. Morrow, W.J.; Isenberg, D.A.; Sobol, R.E.; Stricker, R.B.; Kieber-Emmons, T. AIDS virus infection and autoimmunity: A perspective of the clinical, immunological, and molecular origins of the autoallergic pathologies associated with HIV disease. Clin. Immunol. Immunopathol. 1991, 58, 163-180. [CrossRef]

13. Bjork, R.L. HIV-1: Seven facets of functional molecular mimicry. Immunol. Lett. 1991, 28, 91-96. [CrossRef]

14. Root-Bernstein, R.S.; Hobbs, S.H. Homologies between mycoplasma adhesion peptide, CD4, and class II MHC proteins: A possible mechanism for HIV mycoplasma synergism in AIDS. Res. Immunol. 1992, 142, 519-523. [CrossRef]

15. Root-Bernstein, R.S. Rethinking AIDS. The Tragic Cost of Premature Concensus; Free Press: New York, NY, USA, 1983.

16. Russo, S.; Lopalco, L. Is autoimmunity a component of natural immunity to HIV? Curr. HIV Res. 2006, 4, 177-190. [CrossRef] [PubMed]

17. Huang, Y.M.; Hong, X.Z.; Xu, J.H.; Luo, J.X.; Mo, H.Y.; Zhao, H.L. Autoimmunity and dysmetabolism of human acquired immunodeficiency syndrome. Immunol. Res. 2016, 64, 641-652. [CrossRef] [PubMed]

18. Beretta, A.; Grassi, F.; Pelagi, M.; Clivio, A.; Parravicini, C.; Giovinazzo, G.; Andronico, F.; Lopalco, L.; Verani, P.; Buttò, S. HIV env glycoprotein shares a cross-reacting epitope with a surface protein present on activated human monocytes and involved in antigen presentation. Eur. J. Immunol. 1987, 17, 1793-1798. [CrossRef] [PubMed] 
19. Golding, H.; Robey, F.A.; Gates, F.T.; Linder, W.; Beining, P.R.; Hoffman, T.; Golding, B. Identification of homologous regions in human immunodeficiency virus I gp41 and human MHC class II $\beta 1$ domain. I. Monoclonal antibodies against the gp41-derived peptide and patients' sera react with native HLA class II antigens, suggesting a role for autoimmunity in the pathogenesis of acquired immune deficiency syndrome. J. Exp. Med. 1988, 167, 914-923. [PubMed]

20. Golding, H.; Shearer, G.M.; Hillman, K.; Lucas, P.; Manischewitz, J.; Zajac, R.A.; Clerici, M.; Gress, R.E.; Boswell, R.N.; Golding, B. Common epitope in human immunodeficiency virus (HIV) I-GP41 and HLA class II elicits immunosuppressive autoantibodies capable of contributing to immune dysfunction in HIV I-infected individuals. J. Clin. Invest. 1989, 83, 1430-1435. [CrossRef] [PubMed]

21. Grassi, F.; Meneveri, R.; Gullberg, M.; Lopalco, L.; Rossi, G.B.; Lanza, P.; De Santis, C.; Brattsand, G.; Buttò, S.; Ginelli, E. Human immunodeficiency virus type $1 \mathrm{gp} 120$ mimics a hidden monomorphic epitope borne by class I major histocompatibility complex heavy chains. J. Exp. Med. 1991, 174, 53-62. [CrossRef] [PubMed]

22. Lopalco, L.; de Santis, C.; Meneveri, R.; Longhi, R.; Ginelli, E.; Grassi, F.; Siccardi, A.G.; Beretta, A. Human immunodeficiency virus type 1 gp120 C5 region mimics the HLA class I alpha 1 peptide-binding domain. Eur. J. Immunol. 1993, 23, 2016-2021. [CrossRef] [PubMed]

23. Powell, P.D.; DeMartini, J.C.; Azari, P.; Stargell, L.A.; Cordain, L.; Tucker, A. Evolutionary stable strategy: A test for theories of retroviral pathology which are based upon the concept of molecular mimicry. J. Theor. Biol. 2000, 202, 213-229. [CrossRef] [PubMed]

24. Root-Bernstein, R.S.; Dewitt, S.H. CD4 similarity to proteins of infectious agents in AIDS and their role in autoimmunity. Med. Hypoth. 1994, 43, 361-371. [CrossRef]

25. Root-Bernstein, R.S. Preliminary evidence of idiotype-antiidiotype immune complexes cross reactive with lymphocyte antigens in AIDS and lupus. Med. Hypoth. 1995, 44, 20-27. [CrossRef]

26. Root-Bernstein, R.S. Antigenic complementarity between HIV and other AIDS-associated infections results in idiotype-antiidiotype antibody complexes that cross-react with lymphocyte proteins. Vaccine 2005, 23, 2160-2163. [CrossRef] [PubMed]

27. Root-Bernstein, R.S.; Rallo, A. Antigenic complementarity resulting in idiotype-antiidiotype immune complexes: Possible contributor to AIDS pathogenesis and autoimmunity. Autoimmunity 2004, 37, $203-210$. [CrossRef] [PubMed]

28. Root-Bernstein, R.S. Antigenic complementarity among AIDS-associated infectious agents and molecular mimicry of lympohocyte proteins as inducers of lymphocytotoxic antibodies and circulating immune complexes. J. Clin. Virol. 2004, 31, 16-25. [CrossRef] [PubMed]

29. Trujillo, J.R.; Rogers, R.A.; Brain, J.D. Shared antigenic epitopes on the V3 loop of HIV-1 gp120 and proteins on activated human T cells. Virology 1998, 246, 53-62. [CrossRef] [PubMed]

30. Lake, D.F.; Schlute, S.F.; Wang, E.; Bernstein, R.M.; Edmundson, A.B.; Marchalonis, J.J. Autoantibodies to the $\alpha / \beta$ T-cell receptors in human immunodeficiency virus infection: dysregulation and mimicry. Proc. Natl. Acad. Sci. USA 1994, 91, 10849-10853. [CrossRef] [PubMed]

31. Marchalonis, J.J.; Lake, D.F.; Schluter, S.F.; Dehghanpisheh, K.; Watson, R.R.; Ampel, N.M.; Galgiani, J.N. Autoantibodies against peptide-defined epitopes of T-cell receptors in retrovirally infected humans and mice. Adv. Exp. Med. Biol. 1995, 383, 211-222. [PubMed]

32. Sheikh, J.; Ongradi, J.; Austen, B.; Dalgleish, A. The potential importance of MHC mimicry by HIV in the pathogenesis of AIDS. Biochem. Soc. Trans. 1995, 23, 471-479. [CrossRef]

33. Süsal, C.; Kröpelin, M.; Daniel, V.; Opelz, G. Molecular mimicry between HIV-1 and antigen receptor molecules: A clue to the pathogenesis of AIDS. Vox Sang. 1993, 65, 10-17. [CrossRef] [PubMed]

34. Dalgleish, A.G. Autoimmune mechanisms of depletion of CD4 cells in HIV infection. Br. J. Haematol. 1995, 91, 525-534. [CrossRef] [PubMed]

35. Chen, Y.H.; Xiao, Y.; Dierich, M.P. HIV-1 gp41 and type I interferon: Sequence homology and biological as well as clinical implications. Immunol. Res. 2000, 22, 61-66. [CrossRef]

36. Serres, P.F. AIDS: An immune response against the immune system. Role of a precise tridimensional molecular mimicry. J. Autoimmun. 2001, 16, 287-291. [CrossRef] [PubMed]

37. Sanhadji, K.; Tardy, J.C.; Touraine, J.L. HIV-1 infection: Functional competition between gp41 and interleukin-2. C. R. Biol. 2010, 333, 608-612. [CrossRef] [PubMed]

38. Su, G.; Min, W.; Taylor, E.W. An HIV-1 encoded peptide mimics the DNA binding loop of NF- $\mathrm{kB}$ and binds thioredoxin with high affinity. Mutat. Res. 2005, 579, 133-148. [CrossRef] [PubMed] 
39. Bettaieb, A.; Fromont, P.; Louache, F.; Oksenhendler, E.; Vainchenker, W.; Duédari, N.; Bierling, P. Presence of cross-reactive antibody between human immunodeficiency virus (HIV) and platelet glycoproteins in HIV-related immune thrombocytopenic purpura. Blood 1992, 80, 162-169. [PubMed]

40. Dominguez, V.; Gevorkian, G.; Govezensky, T.; Rodriguez, H.; Viveros, M.; Cocho, G.; Macotela, Y.; Masso, F.; Pacheco, M.; Estrada, J.L.; et al. Antigenic homology of HIV-1 GP41 and human platelet glycoprotein GPIIIa (integrin beta3). J. Acquir. Immune Defic. Syndr. Hum. Retrovirol. 1998, 17, 385-390. [CrossRef] [PubMed]

41. Tishkoff, G.H.; Hunt, L.T. Unexpected molecular mimicry among peptides MHC class II, blood-clotting factor X, and HIV-1 envelope glycoprotein GP120. Thromb. Res. 2000, 98, 343-346. [CrossRef]

42. Tsiakalos, A.; Routsias, J.G.; Kordossis, T.; Moutsopoulos, H.M.; Tzioufas, A.G.; Sipsas, N.V. Fine epitope specificity of anti-erythropoietin antibodies reveals molecular mimicry with HIV-1 p17 protein: A pathogenetic mechanism for HIV-1-related anemia. J. Infect. Dis. 2011, 204, 902-911. [CrossRef] [PubMed]

43. Li, Z.; Nardi, M.A.; Karpatkin, S. Role of molecular mimicry to HIV-1 peptides in HIV-1-related immunologic thrombocytopenia. Blood 2005, 106, 572-576. [CrossRef] [PubMed]

44. Pintér, C.; Siccardi, A.G.; Lopalco, L.; Longhi, R.; Clivio, A. HIV glycoprotein 41 and complement factor H interact with each other and share functional as well as antigenic homology. AIDS Res. Hum. Retroviruses 1995, 11, 971-980. [CrossRef] [PubMed]

45. Wiwanitkit, V. Structural homology of HIV-1 GP41 and human platelet glycoprotein GPIIIa. Blood Coagul. Fibrinolysis 2008, 19, 739-740. [CrossRef] [PubMed]

46. Witte, V.; Laffert, B.; Rosorius, O.; Lischka, P.; Blume, K.; Galler, G.; Stilper, A.; Willbold, D.; D'Aloja, P.; Sixt, M.; et al. HIV-1 Nef mimics an integrin receptor signal that recruits the polycomb group protein Eed to the plasma membrane. Mol. Cell. 2004, 13, 179-190. [CrossRef]

47. Pornillos, O.; Higginson, D.S.; Stray, K.M.; Fisher, R.D.; Garrus, J.E.; Payne, M.; He, G.P.; Wang, H.E.; Morham, S.G.; Sundquist, W.I. HIV Gag mimics the Tsg101-recruiting activity of the human Hrs protein. J. Cell Biol. 2003, 162, 425-434. [CrossRef] [PubMed]

48. Spehar, T.; Strand, M. Cross-reactivity of anti-human immunodeficiency virus type 1 gp41 antibodies with human astrocytes and astrocytoma cell lines. J. Virol. 1994, 68, 6262-6269. [PubMed]

49. Spehar, T.; Strand, M. Molecular mimicry between HIV-1 gp41 and an astrocyte isoform of $\alpha$-actinin. J. Neurovirol. 1995, 1, 381-390. [CrossRef] [PubMed]

50. Yamada, M.; Zurbriggen, A.; Oldstone, M.B.; Fujinami, R.S. Common immunologic determinant between human immunodeficiency virus type 1 gp41 and astrocytes. J. Virol. 1991, 65, 1370-1376. [PubMed]

51. Trujillo, J.R.; McLane, M.F.; Lee, T.H.; Essex, M. Molecular mimicry between the human immunodeficiency virus type 1 gp120 V3 loop and human brain proteins. J. Virol. 1993, 67, 7711-7715. [PubMed]

52. Eddleston, M.; de la Torre, J.C.; Xu, J.Y.; Dorfman, N.; Notkins, A.; Zolla-Pazner, S.; Oldstone, M.B. Molecular mimicry accompanying HIV-1 infection: Human monoclonal antibodies that bind to gp41 and to astrocytes. AIDS Res. Hum. Retroviruses 1993, 9, 939-944. [CrossRef] [PubMed]

53. Atassi, H.; Atassi, M.Z. HIV envelope proteinis recognized as an alloantigen by human DR-specific alloreactive T cells. Hum. Immunol. 1992, 34, 31-38. [CrossRef]

54. Nikolich-Zugich, J.; Slifka, M.K.; Messaoudi, I. The many important facets of T-cell repertoire diversity. Nat. Rev. Immunol. 2004, 4, 123-132. [CrossRef] [PubMed]

55. Berson, S.A.; Yalow, R.S. Quantitative aspects of the reaction between insulin and insulin-binding antibody. J. Clin. Invest. 1959, 38, 1996-2016. [CrossRef] [PubMed]

56. Burch, H.B.; Clement, S.; Sokol, M.S.; Landry, F. Reactive hypoglycemic coma due to insulin autoimmune syndrome: case report and literature review. Am. J. Med. 1992, 92, 681-685. [CrossRef]

57. Suzuki, T.; Nishii, N.; Takashima, S.; Matsubara, T.; Iwasawa, A.; Takeuchi, H.; Tahara, K.; Hachisu, T.; Kitagawa, H. Ligand-binding characteristics of feline insulin-binding immunoglobulin G. J. Vet. Med. Sci. 2015, 77, 1379-1383. [CrossRef] [PubMed]

58. Lin, W.L.; Fincke, J.E.; Sharer, L.R.; Monos, D.S.; Lu, S.; Gaughan, J.; Platsoucas, C.D.; Oleszak, E.L. Oligoclonal $\mathrm{T}$ cells are infiltrating the brains of children with AIDS: Sequence analysis reveals high proportions of identical $\beta$-chain T-cell receptor transcripts. Clin. Exp. Immunol. 2005, 338-356. [CrossRef] [PubMed]

59. Norley, S.; Kurth, R. The role of the immune response during SIVagm infection of the African green monkey natural host. Front. Biosci. 2004, 9, 550-564. [PubMed] 
60. Ansari, A.A. Autoimmunity, anergy, lentiviral immunity and disease. Autoimmun. Rev. 2004, 3, 530-540. [CrossRef] [PubMed]

61. Lucchese, G.; Stufano, A.; Calabro, M.; Kanduc, D. Charting the peptide crossreactome between HIV-1 and the human proteome. Front. Biosci. 2011, 3, 1385-4000. [CrossRef]

62. Venturi, V.; Price, D.A.; Douek, D.C.; Davenport, M.P. The molecular basis for public T-cell responses? Nat. Rev. Immunol. 2008, 8, 231-238. [CrossRef] [PubMed]

63. Miles, J.J.; Douek, D.C.; Price, D.A. Bias in the alphabeta T-cell repertoire: Implications for disease pathogenesis and vaccination. Immunol. Cell Biol. 2011, 89, 375-387. [CrossRef] [PubMed]

64. Zvyagin, I.V.; Pogorelyy, M.V.; Ivanova, M.E.; Komech, E.A.; Shugay, M.; Bolotin, D.A.; Shelenkov, A.A.; Kurnosov, A.A.; Staroverov, D.B.; Chudakov, D.M.; et al. Distinctive properties of identical twins' TCR repertoires revealed by high-throughput sequencing. Proc. Natl. Acad. Sci. USA 2014, 111, 5980-5985. [CrossRef] [PubMed]

65. Williams, W.B.; Liao, H.X.; Moody, M.A.; Kepler, T.B.; Alam, S.M.; Gao, F.; Wiehe, K.; Trama, A.M.; Jones, K.; Zhang, R.; et al. HIV-1 vaccines. Diversion of HIV-1 vaccine-induced immunity by gp41-microbiota cross-reactive antibodies. Science 2015, 349, aab1253. [CrossRef] [PubMed]

66. Rolland, M.; Nickle, D.C.; Deng, W.; Frahm, N.; Brander, C.; Learn, G.H.; Heckerman, D.; Jojic, N.; Jojic, V.; Walker, B.D.; et al. Recognition of HIV-1 peptides by host CTL is related to HIV-1 similarity to human proteins. PLoS ONE 2007, 2, e823. [CrossRef] [PubMed]

67. Van der Kuyl, A.C. HIV infection and HERV expression: A review. Retrovirology 2012, 9, 6. [CrossRef] [PubMed]

68. Seifarth, W.; Frank, O.; Zeilfelder, U.; Spiess, B.; Greenwood, A.D.; Hehlmann, R.; Leib-Mösch, C. Comprehensive analysis of human endogenous retrovirus transcriptional activity in human tissues with a retrovirus-specific microarray. J. Virol. 2005, 79, 341-352. [CrossRef] [PubMed]

69. Nelson, P.N.; Carnegie, P.R.; Martin, J.; Davari Ejtehadi, H.; Hooley, P.; Roden, D.; Rowland-Jones, S.; Warren, P.; Astley, J.; Murray, P.G. Demystified. Human endogenous retroviruses. Mol. Pathol. 2003, 6, 11-18. [CrossRef]

70. Trama, A.M.; Moody, M.A.; Alam, S.M.; Jaeger, F.H.; Lockwood, B.; Parks, R.; Lloyd, K.E.; Stolarchuk, C.; Scearce, R.; Foulger, A.; et al. HIV-1 envelope gp41 antibodies can originate from terminal ileum B cells that share cross-reactivity with commensal bacteria. Cell Host Microbe 2014, 16, 215-226. [CrossRef] [PubMed]

71. Borgdorff, H.; Tsivtsivadze, E.; Verhelst, R.; Marzorati, M.; Jurriaans, S.; Ndayisaba, G.F.; Schuren, F.H.; van de Wijgert, J.H. Lactobacillus-dominated cervicovaginal microbiota associated with reduced HIV/STI prevalence and genital HIV viral load in African women. ISME J. 2014, 8, 1781-1793. [CrossRef] [PubMed]

72. Hearps, A.C.; Tyssen, D.; Srbinovski, D.; Bayigga, L.; Diaz, D.J.; Aldunate, M.; Cone, R.A.; Gugasyan, R.; Anderson, D.J.; Tachedjian, G. Vaginal lactic acid elicits an anti-inflammatory response from human cervicovaginal epithelial cells and inhibits production of pro-inflammatory mediators associated with HIV acquisition. Mucosal Immunol. 2017, in press. [CrossRef] [PubMed]

73. Eade, C.R.; Diaz, C.; Chen, S.; Cole, A.L.; Cole, A.M. HIV-Enhancing factors are secreted by reproductive epithelia upon inoculation with bacterial vaginosis-associated bacteria. Protein Pept. Lett. 2015, 22, 672-680. [CrossRef] [PubMed]

74. Van de Wijgert, J.H.; Jespers, V. The global health impact of vaginal dysbiosis. Res. Microbiol. 2017, in press. [CrossRef] [PubMed]

75. Zabihollahi, R.; Motevaseli, E.; Sadat, S.M.; Azizi-Saraji, A.R.; Asaadi-Dalaie, S.; Modarressi, M.H. Inhibition of HIV and HSV infection by vaginal lactobacilli in vitro and in vivo. DARU J. Pharm. Sci. 2012, 20, 53. [CrossRef] [PubMed]

76. Mirmonsef, P.; Spear, G.T. The barrier to HIV transmission provided by genital tract Lactobacillus colonization. Am. J. Reprod. Immunol. 2014, 1, 531-536. [CrossRef] [PubMed]

77. Petrova, M.I.; van den Broek, M.; Balzarini, J.; Vanderleyden, J.; Lebeer, S. Vaginal microbiota and its role in HIV transmission and infection. FEMS Microbiol. Rev. 2013, 37, 762-792. [CrossRef] [PubMed]

78. Ziegler, J.L.; Stites, D.P. Hypothesis: AIDS is an autoimmune disease directed at the immune system and triggered by a lymphotropic retrovirus. Clin. Immunol. Immunopathol. 1986, 41, 305-313. [CrossRef]

79. Stott, E.J. Anti-cell antibody in macaques. Nature 1991, 353, 393-395. [CrossRef] [PubMed]

80. Kion, T.A.; Hoffmann, G.W. Anti-HIV and anti-anti-MHC antibodies in alloimmune and autoimmune mice. Science 1991, 253, 1138-1140. [CrossRef] [PubMed] 
81. Hoffmann, G.W.; Kion, T.A.; Grant, M.D. An idiotypic network model of AIDS immunopathogenesis. Proc. Natl. Acad. Sci. USA 1991, 88, 3060-3064. [CrossRef] [PubMed]

82. Schacker, T.W.; Reilly, C.; Haase, A.T. Collagen deposition in HIV-1 infected lymphatic tissues and T cell homeostasis. J. Clin. Invest. 2002, 110, 1133-1139. [CrossRef] [PubMed]

83. Lopalco, L.; Burastero, S.E. HIV-1 and the self-nonself connection: How to sleep with the enemy and be much better off. AIDS Rev. 2008, 10, 162-171. [PubMed]

84. Stratov, I.; DeRose, R.; Purcell, D.F.; Kent, S.J. Vaccines and vaccine strategies against HIV. Curr. Drug Targets 2004, 5, 71-88. [CrossRef] [PubMed]

85. Ersching, J.; Pinto, A.R. HIV-1 vaccine clinical trials: the Brazilian experience. Rev. Med. Virol. 2009, 19, 301-311. [CrossRef] [PubMed]

86. Root-Bernstein, R.S. Five myths about AIDS that are misdirecting research and treatment. Genetica 1995, 95, 100-132. [CrossRef]

87. Keay, S.; Tacket, C.O.; Murphy, J.R.; Handwerger, B.S. Anti-CD4 anti-idiotype antibodies in volunteers immunized with rgpl60 or HIV-1 or infected with HIV-1. AIDS Res. Human Retroviruses 1992, 8, 1091-1098. [CrossRef] [PubMed]

88. De Santis, C.; Robbioni, P.; Longhi, R.; Lopalco, L.; Siccardi, A.G.; Beretta, A.; Roberts, N.J. Cross-reactive response to human immunodeficiency virus type 1 (HIV-1) gp120 and HLA class I heavy chains induced by receipt of HIV-1-derived envelope vaccines. J. Infect. Dis. 1993, 168, 1396-1403. [CrossRef] [PubMed]

89. Zhang, R.; Verkoczy, L.; Wiehe, K.; Alam, S.M.; Nicely, N.I.; Santra, S.; Bradley, T.; Pemble, C.W.; Zhang, J.; Gao, F.; Monefiori, D.C.; et al. Initiation of immune tolerance-controlled HIV gp41 neutralizing B cell lineages. Sci. Trans. Med. 2016, 8, 336ra62. [CrossRef] [PubMed]

90. Moody, M.A.; Pedroza-Pacheco, I.; Vandergrift, N.A.; Chui, C.; Lloyd, K.E.; Parks, R.; Soderberg, K.A.; Ogbe, A.T.; Cohen, M.S.; Liao, H.-X.; Gao, F.; et al. Immune perturbations in HIV-1-infected individuals who make broadly neutralizing antibodies. Sci. Immun. 2016, 1, aag0851. [CrossRef] [PubMed]

91. Bradac, J.; Dieffenbach, C.W. HIV vaccine development: Lessons from the past, informing the future. Invest. Drugs J. 2009, 12, 435-439.

92. Shearer, G.M.; Pinto, L.A.; Clerici, M. Alloimmunization for immune-based therapy and vaccine design against HIV / AIDS. Immunol. Today 1999, 20, 66-71. [CrossRef]

93. Bourinbaiar, A.; Root-Bernstein, R.S.; Abulafia-Lapid, R.; Rytik, P.G.; Kanev, A.N.; Orlovsky, V.G. Therapeutic HIV vaccines. Curr. Pharm. Design 2006, 12, 2017-2030. [CrossRef]

94. Root-Bernstein, R.S.; Bernstein, M. SIV as a human vaccine against HIV? J. Theor. Biol. 1996, 180, 91-92. [CrossRef]

95. Kou, Z.C.; Puhr, J.S.; Wu, S.S.; Goodenow, M.M.; Sleasman, J.W. Combination antiretroviral therapy results in a rapid increase in T cell receptor variable region $\beta$ repertoire diversity within CD45RA CD8 T cells in human immunodeficiency virus-infected children. J. Infect. Dis. 2003, 187, 385-395. [CrossRef] [PubMed]

96. McFarland, E.J.; Harding, P.A.; Striebich, C.C.; McWhinney, S.; Kuritzkes, D.R.; Kotzin, B.L. Clonal CD8+ T Cell expansions in peripheral blood from human immunodeficiency virus type 1-infected children. J. Infect. Dis. 2002, 186, 477-485. [CrossRef] [PubMed]

97. Weekes, M.P.; Carmichael, A.J.; Wills, M.R.; Mynard, K.; Sissons, J.G.P. Human CD38-CD8+ T cells contain greatly expanded functional virus-specific memory CTL clones. J. Immunol. 1999, 162, 7569-7577. [PubMed]

98. Rudensky, A.Y.; Preston-Hurlburt, P.; Hong, S.C.; Barlow, A. Sequence analysis of peptides bound to MHC class II molecules. Nature 1991, 353, 622-627. [CrossRef] [PubMed]

99. Cunningham, M.W.; McCormack, J.M.; Fenderson, P.G.; Ho, M.K. Human and murine antibodies cross-reactive with streptococcal $M$ protein and myosin recognize the sequence GLN-LYS-SER-LYS-GLN in M protein. J. Immunol. 1989, 143, 2677-2683. [PubMed]

100. Root-Bernstein, R.S.; Podufaly, A. Autoreactive T-cell receptor $(\mathrm{V} \beta / \mathrm{D} / \mathrm{J} \beta)$ sequences in diabetes recognize insulin, the insulin receptor, and each other, and are targets of insulin antibodies. Open Autoimmun. J. 2012, 4, 10-22. [CrossRef]

101. Root-Bernstein, R.S. Rethinking molecular mimicry in rheumatic heart disease and autoimmune myocarditis: Laminin, collagen IV, CAR, and B1AR as initial targets of disease. Front. Ped. Rheumatol. 2014, 2, 85. [CrossRef] [PubMed] 
102. Matsushita, S.; Robert-Guroff, M.; Rusche, J.; Koito, A.; Hattori, T.; Hoshino, H.; Javaherian, K.; Takatsuki, K.; Putney, S. Characterization of a Human immunodeficiency virus neutralizing monoclonal antibody and mapping of the neutralizing epitope. J. Virol. 1998, 62, 2107-2114.

103. Hauber, J.; Perkins, A.; Heimer, E.; Cullen, B. Trans-activation of human immunodeficiency virus gene expression is mediated by nuclear events. Proc. Natl. Acad. Sci. USA 1987, 84, 6364-6368. [CrossRef] [PubMed]

104. Rasmussen, L.; Mullenax, J.; Nelson, R.; Merigan, T. Viral polypeptides detected by a complement-dependent neutralizing murine monoclonal antibody to human cytomegalovirus. J. Virol. 1985, 55, 274-280. [PubMed]

105. Shugars, D.C.; Smith, M.S.; Glueck, D.H.; Nantermet, P.V.; Seillier-Moiseiwitsch, F.; Swanstrom, R. Analysis of human immunodeficiency virus type 1 nef gene sequences present in vivo. J. Virol. 1993, 67, 4639-4650. [PubMed]

106. Hagen, M.D.; Meyer, K.B.; Kopelman, R.I.; Pauker, S.G. Human immunodeficiency virus infection in health care workers. A method for estimating individual occupational risk. Arch. Intern. Med. 1989, 49, 1541-1544. [CrossRef]

107. Boily, M.C.; Baggaley, R.F.; Wang, L.; Masse, B.; White, R.G.; Hayes, R.J. Heterosexual risk of HIV-1 infection per sexual act: Systematic review and meta-analysis of observational studies. Lancet Infect. Dis. 2009, 9, 118-129. [CrossRef]

108. Sonnabend, J.A.; Saadoun, S. The acquired immunodeficiency syndrome: A discussion of etiologic hypotheses. AIDS Res. 1983, 1, 107-120. [CrossRef] [PubMed]

109. Sonnabend, J.A.; Witkin, S.S.; Purtilo, D.T. A multifactorial model for the development of AIDS in homosexual men. Ann. N. Y. Acad. Sci. 1984, 437, 177-183. [CrossRef] [PubMed]

110. Root-Bernstein, R.S. Do we know the cause(s) of AIDS? Persp. Biol. Med. 1990, 33, 480-500. [CrossRef]

111. Pattacini, L.; Baeten, J.M.; Thomas, K.K.; Fluharty, T.R.; Murnane, P.M.; Donnell, D.; Bukusi, E.; Ronald, A.; Mugo, N.; Lingappa, J.R.; et al. Regulatory T-cell activity but not conventional HIV-specific T-Cell responses are associated with protection from HIV-1 infection. J. Acquir. Immune Defic. Syndr. 2016, 72, 119-128. [CrossRef] [PubMed]

(C) 2017 by the author. Licensee MDPI, Basel, Switzerland. This article is an open access article distributed under the terms and conditions of the Creative Commons Attribution (CC BY) license (http:/ / creativecommons.org/licenses/by/4.0/). 